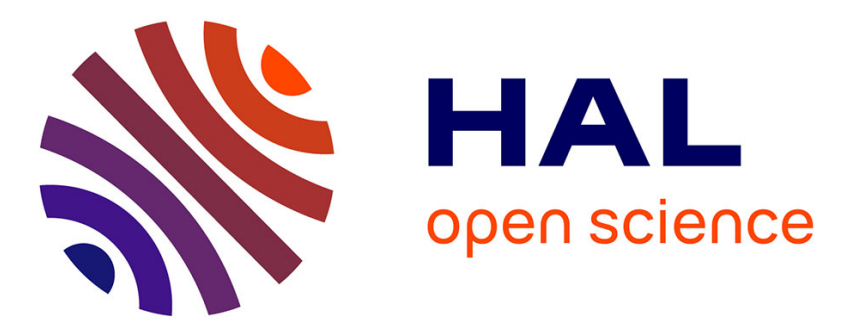

\title{
Rare earth element fractionation in heterogenite (CoOOH): Implication for cobalt oxidized ore in the Katanga Copperbelt (Democratic Republic of Congo)
}

Sophie Decree, Olivier Pourret, Jean-Marc Baele

\section{- To cite this version:}

Sophie Decree, Olivier Pourret, Jean-Marc Baele. Rare earth element fractionation in heterogenite $(\mathrm{CoOOH})$ : Implication for cobalt oxidized ore in the Katanga Copperbelt (Democratic Republic of Congo). Journal of Geochemical Exploration, 2015, 159, pp.290-301. 10.1016/j.gexplo.2015.10.005 . hal-02136370

\author{
HAL Id: hal-02136370 \\ https://hal.science/hal-02136370
}

Submitted on 22 May 2019

HAL is a multi-disciplinary open access archive for the deposit and dissemination of scientific research documents, whether they are published or not. The documents may come from teaching and research institutions in France or abroad, or from public or private research centers.
L'archive ouverte pluridisciplinaire HAL, est destinée au dépôt et à la diffusion de documents scientifiques de niveau recherche, publiés ou non, émanant des établissements d'enseignement et de recherche français ou étrangers, des laboratoires publics ou privés. 
1 Rare earth element fractionation in heterogenite $(\mathrm{CoOOH})$ :

2 Implication for cobalt oxidized ore in the Katanga Copperbelt

3 (Democratic Republic of Congo)

4

5 Sophie Decrée ${ }^{\mathrm{a}, \mathrm{b}}$, Olivier Pourret ${ }^{\mathrm{c}}$ and Jean-Marc Baele ${ }^{\mathrm{d}}$

6

$7 \quad{ }^{a}$ Royal Belgian Institute of Natural Sciences, Geological Survey of Belgium, Rue Vautier 13,

8 B-1000 Brussels (Belgium). E-mail: sophie.decree@ naturalsciences.be; phone number:

$9 \quad+32.2 .627 .43 .23$

$10{ }^{\mathrm{b}}$ Royal Museum for Central Africa, 3080 Tervuren, Belgium

$11{ }^{c}$ HydrISE, LaSalle Beauvais, 60026 Beauvais cedex, France. E-mail : olivier.pourret@lasalle-

12 beauvais.fr

13

${ }^{\mathrm{d}}$ University of Mons (Belgium). E-mail: jean-marc.baele@umons.ac.be

\section{Abstract}

Heterogenite $(\mathrm{CoOOH})$ is the most abundant cobalt oxide mineral in the Katanga Copperbelt, which hosts around half of the world's known reserves of mineable cobalt. Heterogenite

18 formed by the oxidation of Co-sulfides and accumulated as residual deposits during a

19 Pliocene weathering event. Bulk analysis samples of oxidized cobalt ore samples containing

20 with variable heterogenite concentration display two rare earth element (REE) patterns: (i)

21 Type 1 is enriched in middle REE, with a negative cerium anomaly and a relatively low REE

22 content; (ii) Type 2 is variably enriched in light REE (LREE), without a cerium anomaly and 
1 with higher REE content. However, in situ LA-ICP-MS reveals that the Type 2 patterns are

2 due to the mixing of heterogenite with a LREE-rich mineral.

Weathering processes leading to heterogenite formation mainly consist of water-rock

4 interactions at high Co activity, in the near-surface environment. These result in the formation

5 of a lateritic deposit. Heterogenite precipitates at near-neutral $\mathrm{pH}$ conditions together with

6 manganese oxides. REE are mainly fractionated between these Co-and Mn-oxide minerals. In

7 the deeper part of the oxidized profile, cobalt activity decreases and the heterogenite stability

8 field shifts to alkaline $\mathrm{pH}$ conditions due to the dissolution of dolostone in the bedrock. In

9 such an alkaline environment, REE speciation is mainly driven by carbonate

10 complexation/precipitation. This environment would be favorable for the formation of REE-

11 rich carbonate which is intimately associated with heterogenite (LREE-rich Type 2 patterns).

12 The combined whole-rock and in situ geochemical analyses presented here clearly

13 help (1) to distinguish the REE signature of the Co oxidized ore (mineral paragenesis

14 comprizing heterogenite) and of heterogenite itself, and subsequently (2) to highlight two

15 different chemical environments for the formation of heterogenite in supergene ores. This

16 study therefore improves the understanding of REE behaviour and metal mobility in near-

17 surface environments, and more particularly in environments where the supergene ores form.

18 In the future, the approach developped here can be applied to other Co-Ni-Mn lateritic

19 deposits such as those in New-Caledonia and Cameroon.

21 Keywords: Cobalt, lanthanide, Katanga, Democratic Republic of Congo, Manganese oxide, 22 LA-ICP-MS

\section{1. Introduction}


1 The Katanga Copperbelt is situated in the southeastern Democratic Republic of Congo, which

2 is part of the Lufilian fold-and-thrust belt and hosts $\sim 45 \%$ of the world's known reserves of 3 mineable cobalt (3.4 Mt Co metal content; USGS, 2014). works on the Katanga heterogenite (Hey, 1962; Deliens, 1974; Deliens and Goethals, 1973;

6 Gauthier and Deliens, 1999; Burlet et al., 2011; Vanbrabant, 2013) distinguished two sub7 types of heterogenite: (i) rhombohedral heterogenite 3R is the most abundant variety (Deliens, 8 1974), and (ii) heterogenite $2 \mathrm{H}$, which is a hexagonal polytype defined by Deliens and 9 Goethals (1973). Recent Raman microspectroscopy analyses coupled with electron backscattered diffraction (EBSD), however have shown that heterogenite is commonly poorly crystallized Burlet et al. (2011).

In the Katanga Copperbelt, heterogenite is derived from the oxidation of primary sulfide minerals hosted in stratiform deposits. Mio-Pliocene weathering strongly concentrated Co in the near-surface oxidized ore, within the so-called "cobalt-cap" (Decrée et al., 2010; Gauthier and Deliens, 1999). The genesis of heterogenite in the general Mio-Pliocene geodynamic framework in the Katanga has been recently reinvestigated by Decrée et al. 17 (2010).

Here, further insights into the processes responsible for heterogenite formation are investigated through the study of rare earth elements (REE) distribution. This is a powerful tool in understanding the formation of oxi-hydroxides (Pourret and Davranche, 2013) since the fractionation of REE can be used as a tracer of these processes.

In this paper, the REE distribution is studied on mineral separates that remain variably 23 admixed with the host rock. These samples are therefore representative of the bulk Co 24 oxidized ore. They are investigated using X-Ray diffraction and scanning electron microscopy 25 (SEM) with energy-dispersive spectroscopy (EDS) in order to determine their mineralogical 
1 assemblage. Besides these bulk analyses, in situ (electron microprobe and LA-ICP-MS)

2 analyses have been acquired, avoiding any contamination from the host rock. The REE

3 signature of heterogenite is obtained using the LA-ICP-MS. The electron microprobe analyses

4 are needed to determine how much the heterogenite is mixed with Mn oxi-hydroxides. This

5 parameter is important since Mn oxi-hydroxides are known to strongly affect the REE

6 behaviour. Eventually, modeling is used to predict how the REE speciation and how these

7 elements should behave in a multi-ligand groundwater in the presence of Mn oxi-hydroxide.

All together, these data allow to investigate precisely the REE speciation in relation

9 with the geochemistry (and mineralogy) of heterogenite (and Co oxidized ore) samples.

10 Therefore, they can be used to clarify the processes leading to the formation of Co oxidized

11 ore during the weathering in the Katanga Copperbelt.

At a larger scale, the study dedicated to the REE behavior in heterogenite could be applied to other Co-Ni-Mn oxide mineralizations that form laterite (on serpentinized ultramafic rocks), as those present in New Caledonia (Llorca and Monchoux 1991), Cuba (Moa Bay; Roqué-Rossell et al. 2010), Cameroon (Nkamouna; Dzemua et al. 2013), Colombia (Cerro Matoso; Gleeson et al., 2004), Australia (Greenvale; Zeissink, 1969) and USA (Oregon; Hotz, 1964).

\section{Geological setting}

The $\mathrm{Cu}-\mathrm{Co}$ deposits of the Katanga Copperbelt are predominantly hosted in the lower part of the Neoproterozoic Katanga Supergroup (Roan Group, 880-730 Ma; Kampunzu et al., 2009)

(Figure 1). The overlying deposits are part of the barren upper Roan (R-4, Mwashya Subgroup), Nguba (730-635 Ma) and Kundelungu (635- 573 Ma) Groups (ages after

24 Kampunzu et al., 2009). The primary stratabound $\mathrm{Cu}-\mathrm{Co}$ mineralization is typically hosted by 
1 breccias on Figure 1). These host-rocks comprise dolomitic siltstones, stromatolitic

2 dolostones, siltstones, dolomitic and carbonaceous shales, together with local sandstones and

3 arkoses (Cailteux et al., 2005). The mineralization is also observed in brecciated and faulted

4 lithotypes occurring mainly in the lower part of the Kundelungu Group (Figure 1). The

5 primary stratiform $\mathrm{Cu}$-Co sulfide mineralization is early syn-diagenetic (Dewaele et al., 2006;

6 El Desouky et al., 2010; Muchez et al., 2008) and occurred around 820 Ma (Selley et al.,

7 2005) and/or after $\sim 750$ Ma (Hitzman et al., 2005). Later mineralization events took place

8 before or during the pan-African Lufilian folding (Cailteux et al., 2005; Decrée et al., 2011;

9 Decrée et al., 2014; Dewaele et al., 2006; El Desouky et al., 2009; Haest and Muchez, 2011;

10 Haest et al., 2007; Haest et al., 2009; Kampunzu et al., 2009). In these primary deposits,

11 carrollite $\left(\mathrm{CuCo}_{2} \mathrm{~S}_{4}\right)$, siegenite $\left((\mathrm{Ni}, \mathrm{Co})_{3} \mathrm{~S}_{4}\right)$ and linnaeite $\left(\mathrm{Co}^{2+} \mathrm{Co}^{3+}{ }_{2} \mathrm{~S}_{4}\right)$ are the most abundant 12 primary cobalt ore minerals.

13 The post-orogenic history of the mineralization is poorly known. During this period,

14 the Lufilian fold-and-thrust belt underwent various stages of weathering and erosional 15 episodes. As a result, the sulfide ore deposits are now oxidized, usually down to a depth of $16 \sim 100 \mathrm{~m}$ (Ngongo, 1975). Recent studies have shown that the Katanga $\mathrm{Cu}-\mathrm{Co}$ oxidized ore is 17 the result of a Pliocene weathering/oxidizing episode (SIMS U-Pb age of the heterogenite is dated at $3.4 \pm 0.8 \mathrm{Ma}$; Decrée et al., 2010). This weathering process is economically significant because it strongly concentrated $\mathrm{Co}$ in the supergene ore when compared to the primary ore (64\% Co for heterogenite v. $39 \%$ Co for carrollite). Heterogenite is thought to have formed in (sub)surface oxidizing conditions, whereas $\mathrm{Cu}$ migrates deeper downward and precipitates as malachite near the water table (De Putter et al., 2010; Decrée et al., 2010). Heterogenite caps can therefore be considered as a residual deposit, similar to iron-rich 24 laterites.

\section{Material and methods}


1 The 24 heterogenite samples studied here originate from cobalt caps in 14 mines (see location

2 on Figure 1). The samples were either collected in the field or recovered from the mineral

3 collection in the Royal Museum for Central Africa, Tervuren, Belgium (Table 1). Mineral

4 separates of these samples have been prepared. However, due to the intimate mixing of

5 heterogenite with the host rock (especially when heterogenite impregnates earthy material),

6 these samples are more representative of the bulk ore than pure heterogenite.

7 The texture of the samples was studied using scanning electron microscopy (SEM) on

8 a Quanta 20 ESEM (FEI), with energy-dispersive spectroscopy (Apollo 10 Sillicon Drift

9 EDS detector; EDAX) at the Royal Belgian Institute of Natural Sciences. The mineralogy of

10 the rock samples was determined using a Bruker-Siemens X-ray micro-diffraction

11 instrument equipped with a $\mathrm{Cu} \mathrm{K \alpha}$ X-ray tube (operating at $40 \mathrm{kV}$ and $30 \mathrm{~mA}$ ), and a

12 General Area Detector Diffraction System (GADDS) detector system at the "Laboratoire de 13 Géochimie et Minéralogie appliquée" (Université Libre de Bruxelles), Belgium. Samples 14 were scanned from $2-70^{\circ} 2 \theta$ and the software EVA 2, version 13 equipped with the JCPDS 15 PDF-2 database (ICDD, 2003) was used for qualitative analysis of XRD patterns.

Quantitative micro-analyzes were acquired using a Cameca SX50 electron microprobe at the University of Mons operated at $15 \mathrm{kV} / 20 \mathrm{nA}$ with a defocused $20 \mu \mathrm{m}$ diameter beam (Supplementary material, Table 1). The microprobe is equipped with four wavelengthdispersive (WDS) spectrometers and standard LIF, PET, TAP and PCs crystals.

Geochemical analyzes (major and trace elements, Supplementary material, Tables 2 and 3)

21 were performed on representative powders (50 grams) of the heterogenite separates/Co

22 oxidized ore at Actlabs, Ontario, Canada. To get the major elements and REE contents, the 23 samples have been dissolved by lithium metaborate/tetraborate fusion, then digested in weak 24 nitric acid solution before being analyzed by ICP-MS. Co and Cu contents have been obtained 
1 after acid digestion by four different acids (hydrochloric, nitric, perchloric and hydrofluoric)

2 and ICP-OES analyses.

Laser ablation ICP-MS measurements (Supplementary material, Table 4) were

4 performed at the Geology and Mineralogy Department, Royal Museum for Central Africa,

5 Belgium. A New-Wave UP-193 FX fast excimer (193 nm) laser coupled with a Thermo

6 Scientific X-Series2 quadrupole ICP-MS was used. The laser was run at $50 \mathrm{~Hz}$ and a fluence

7 of $10 \mathrm{~J} / \mathrm{cm}^{2}$ for a $100 \mu \mathrm{m}$ spot size. He gas was flushed into the ablation cell at a flow rate of

$80.65 \mathrm{~L} / \mathrm{min}$ and was mixed afterwards in the cell with Ar carrier gas at a flow rate of 0.76

$9 \mathrm{~L} / \mathrm{min}$. Co has been used as an internal standard for correcting instrumental drift and ablation

10 rate. The NIST SRM 614, 612 and 610 were used as external standards and were measured

11 frequently during the course of analyzes. The precision at 1 sigma level on the NIST SRM

12612 is below $10 \%$ RSD.

The stability diagrams were modelled using the computer programs PHREEQC

14 (Parkhurst and Appelo, 1999) and PhreePlot (Kinniburgh and Cooper, 2009). Both programs

15 used the llnl.dat data base, which was modified to include well-accepted infinite-dilution (25

$16{ }^{\circ} \mathrm{C}$ ) stability constants for Co and Mn (Chivot et al., 2008; Collins and Kinsela, 2010; Hem et 17 al., 1985).

The speciation calculations were performed using the computer program PHREEQC (Parkhurst and Appelo, 1999) using NAGRA/PSI data base (Hummel et al., 2002), which was modified to include well-accepted infinite-dilution $\left(25{ }^{\circ} \mathrm{C}\right)$ stability constants for REE 21 inorganic complexes (hydroxide, fluoride, chloride, sulfate and carbonate; Klungness and Byrne, 2000; Luo and Byrne, 2004; Migdisov et al., 2009; Schijf and Byrne, 2004) and

23 surface complexation with hydrous manganese oxides (Pourret and Davranche, 2013).

\section{Results}


1 4.1. Typology, paragenesis and chemistry of the Katanga heterogenite

2 Macroscopically, the heterogenite specimens studied here occur as: (i) large (cm scale)

3 reniform masses, (ii) massive impregnation of the silicified host-rock, in which quartz

4 constitutes the dominant mineral phase, or (iii) earthy material finely admixed with the host-

5 rock at an infra- $\mu \mathrm{m}$ scale, i.e. which is not visible using the SEM (see Table 1 for further

6 details). Under the microscope, heterogenite (3R polytype, see XRD patterns in Figure 2) is

7 commonly present as small and finely laminated ( $\mu \mathrm{m}$ to $\mathrm{mm}$-thick laminae) nodular

8 aggregates or botryoids (Figure 3A-L). These nodules include intercalations of heterogenite

9 finely co-precipitated with $\mathrm{Mn}(-\mathrm{Fe})$ with oxides (mostly manganite and asbolane, as

10 determined using XRD) and growths on a core made up of goethite or lepidocrocite (Figure

11 2). In the samples where heterogenite impregnates the host-rock or exhibits an earthy texture,

12 quartz grains or phyllosilicate flakes are enclosed within the Co oxide (Figures 3B,C,D,K).

13 Cuprite is present in association with heterogenite in several samples (Figures 3C,D).

From a geochemical point of view, heterogenite shows a wide range of Co concentration (16.9-86.4 wt. $\left.\% \mathrm{Co}_{2} \mathrm{O}_{3}\right)$. The low Co content is generally related to the enrichment in other metals such as $\mathrm{Cu}$ (up to 24.5 wt. \% $\mathrm{CuO}$ ), $\mathrm{Fe}$ (up to 3.1 wt. $\% \mathrm{Fe}_{2} \mathrm{O}_{3}$ ), Mn (up to 54.6 wt. $\% \mathrm{MnO}_{2}$ ), or $\mathrm{Ni}$ (up to $20.6 \mathrm{wt}$. \% $\mathrm{NiO}$ ). This is likely due to (1) the coprecipitation/intergrowth of heterogenite with other oxides, (2) metal substitution in the crystal lattice of heterogenite, and (3) the adsorption of these elements onto heterogenite. Low to moderate $\mathrm{P}$ enrichment (up to 1.9 wt. $\% \mathrm{P}_{2} \mathrm{O}_{5}$ ) is observed in heterogenite. They are 21 presumably related to the coprecipitation of heterogenite with secondary minerals resulting 22 from the weathering of phosphates associated with Co-sulfides in the primary paragenesis. In 23 addition, heterogenite may be enriched in $\mathrm{U}$ (from a few $\mathrm{mg} / \mathrm{kg}$ to $3.2 \mathrm{wt} \%$ ) and $\mathrm{Pb}$ (see 24 Decrée et al., 2014 for additional data about samples GE 10788 and GE 10816). 
Among the minerals that form in Co-Ni-Mn laterite-like deposits, heterogenite shows

2 the highest Co contents when compared to (1) absolane-lithiophorite minerals from

3 Nkamouna (2.3-17.0 wt.\% CoO; Dzemua et al., 2013), New Caledonia (0.9-12.6 wt.\% CoO;

$4 \quad$ Llorca and Monchoux 1991) and Moa Bay (1.2-7.8 wt.\% CoO; Roqué-Rossell et al., 2010)

5 and (2) cryptomelane, pyrolusite and other Mn oxides from Nkamouna (with 0.7-16.9 wt.\%

6 CoO; Dzemua et al., 2013). Additionally, most of the Katanga heterogenites possess the

7 highest ratios of $\mathrm{Co}$ against $\mathrm{Mn}, \mathrm{Al}, \mathrm{Ni}$, and plot very close to the Co pole in Co-Al-Ni and

8 Co-Ni-Mn ternary diagrams (Figure 4). Heterogenite in Mn-rich layers are rather close in

9 composition to the pyrolusite and "lithiophorite-asbolane intermediate" from the Nkamouna 10 area.

4.2. Heterogenite separates - cobalt oxidized ore (whole rock signatures)

Selected major and trace elements of the studied samples are presented as Supplementary

material. Heterogenite is characterized by high but variable Co contents, ranging from 18.44 to 68.79 wt.\% $\mathrm{CoO}$. It also contains variable contents of $\mathrm{Cu}(0.48-16.8$ wt.\% $\mathrm{CuO}), \mathrm{Mn}(0.01-$ 4.81 wt. $\% \mathrm{MnO})$ and $\mathrm{Fe}\left(0.12-16.26\right.$ wt. $\left.\% \mathrm{Fe}_{2} \mathrm{O}_{3}(\mathrm{t})\right)$. These elements are part of the heterogenite structure or represent a fine admixture of cuprite or Fe/Mn-oxides (see Figure 1). The high $\mathrm{SiO}_{2}$ contents observed in most samples are due remnants of host-rock minerals in the Co oxidized ore (e.g., in Figure 3B). The high $\mathrm{P}_{2} \mathrm{O}_{5}$ contents in samples RGM 4418 and RGM 13025 are attributed to the presence of phosphates. Three analyzed samples (i.e., RGM 3335, RGM 14091 and RGM 10794), which are admixed with Mn-oxides or the hostrocks, show particularly low Co contents (i.e., 11.25, 4.79 and 2.64wt.\% CoO, respectively). Co enrichment in Katanga heterogenite ore is particularly well highlighted in the Co$\mathrm{Al}-\mathrm{Ni}$ and $\mathrm{Co}-\mathrm{Ni}-\mathrm{Mn}$ diagrams (Figure 4), when compared to Co-bearing nickeliferous laterites from Cerro Matoso (Colombia), Greenvale (Australia) and Oregon (USA). In these 
1 lateritic ores, the $\mathrm{CoO}$ content is below 0.6 wt.\% (Gleeson et al., 2004; Hotz, 1964; Zeissink, 2 1969).

4 4.3. Rare earth element signatures

\subsubsection{Heterogenite separates - cobalt oxidized ore (whole rock signatures)}

6 The Upper Continental Crust (UCC)-normalized rare earth element (REE) analyzes of the 7 heterogenite samples show three distinct types of patterns. Type 1 patterns show low total 8 REE abundance $(14<\Sigma \mathrm{REE}<122 \mathrm{mg} / \mathrm{kg}$, with a mean value of $70 \mathrm{mg} / \mathrm{kg})$ and displays a 9 distinctive bell-shaped pattern (Figure 5A), with $\log (\mathrm{La} / \mathrm{Sm})_{\mathrm{UCC}}<1$ and $\log (\mathrm{Gd} / \mathrm{Yb})_{\mathrm{UCC}}>1$ 10 (quadrant 1 in Figure 6A). These samples commonly show a negative cerium anomaly 11 (Ce/Ce* from 0.1 to 1$)$, with no significant europium anomaly (Eu/Eu* from 0.7 to 1.6 with 12 an exception at 3 for sample RGM 2839). Type 2 patterns show REE light REE (LREE) enrichment $\left(\Sigma \mathrm{REE}=524\right.$ and $1436 \mathrm{mg} / \mathrm{kg} ; \mathrm{La}_{\mathrm{ucc}} / \mathrm{Yb}_{\mathrm{ucc}}=30$ and 73 ; Figure 5B$)$, with $\log$ $(\mathrm{La} / \mathrm{Sm})_{\mathrm{UCC}}>0$ and $\log (\mathrm{Gd} / \mathrm{Yb})_{\mathrm{UCC}}>0$ (quadrant 2 in Figure 6A). There is no significant $\mathrm{Ce}$ anomaly $\left(\mathrm{Ce} / \mathrm{Ce}^{*}=0.6\right.$ and 1$)$ and the Eu anomaly is slightly positive or negative $(\mathrm{Eu} / \mathrm{Eu} *=$ 0.4 and 1.2). Type 3 patterns are rather flat from La to Eu but with a slight Heavy REE (HREE) fractionation (Figure 5C). It is intermediately enriched in REE ( $\mathrm{REE}=133$ and 142 $\mathrm{mg} / \mathrm{kg})$ compared to the other types, with a positive $\mathrm{Eu}$ anomaly $\left(\mathrm{Eu} / \mathrm{Eu}^{*}=1.6\right.$ and 1.8$)$ and no marked Ce anomaly $\left(\mathrm{Ce} / \mathrm{Ce}^{*}=\sim 0.8\right)$. In the $\log (\mathrm{Gd} / \mathrm{Yb})_{\mathrm{UCC}}$ vs. $\log (\mathrm{La} / \mathrm{Sm})_{\mathrm{UCC}}$ diagram (Figure 6A), these heterogenites plot at the boundary between quadrant 1 and 2.

\subsubsection{LA-ICP-MS signatures}

23 Due to the intimate mixing of heterogenite with host rock minerals in the impregnation and 24 earthy facies, in situ (LA ICP-MS) analyzes have been performed to obtain the REE signature 25 of these minerals. Compared to the corresponding whole rock patterns, the Type 1 LA-ICP- 
1 MS REE patterns display a similar MREE enrichment (Figure 5D), with quite comparable

2 REE contents $(4<\Sigma$ REE $<111 \mathrm{mg} / \mathrm{kg}$, with an exception at $321 \mathrm{mg} / \mathrm{kg}$ for sample RGM

3 13017), and negative or slightly positive $\mathrm{Ce}$ and $\mathrm{Eu}$ anomalies $(0.01<\mathrm{Ce} / \mathrm{Ce} *<1.4$ and

$4 \quad 0.3<\mathrm{Eu} / \mathrm{Eu}^{*}<1.3$, with an exception at 2.5 for sample RGM 12979). On the other hand, LA-

5 ICP-MS REE patterns obtained on Type 2 heterogenites differ from the whole rock REE

6 patterns (Figure 5E): they are slightly HREE or MREE-enriched, with negative $\mathrm{Ce}$ and $\mathrm{Eu}$

7 anomalies $\left(0.02<\mathrm{Ce} / \mathrm{Ce}^{*}<0.8\right.$ and $\left.0.4<\mathrm{Eu} / \mathrm{Eu}^{*}<1.1\right)$. In addition, the total REE contents are

8 very low (from 2 to $7 \mathrm{mg} / \mathrm{kg}$ ). LA-ICP-MS REE patterns for the third type of heterogenites

9 resemble those obtained from whole rock analyzes, with negative $\mathrm{Ce}$ anomaly $(\mathrm{Ce} / \mathrm{Ce} *=0.5$

10 and 0.7$)$ and positive Eu anomaly $\left(\mathrm{Eu} / \mathrm{Eu}^{*}=1.2\right.$ and 1.3$)$. They are however less enriched in

11 REE ( $\Sigma \mathrm{REE}=30$ and $49 \mathrm{mg} / \mathrm{kg})$, especially in LREE, highlighting a slight MREE enrichment

12 in the patterns. In the $\log (\mathrm{Gd} / \mathrm{Yb})_{\mathrm{UCC}}$ vs. $\log (\mathrm{La} / \mathrm{Sm})_{\mathrm{UCC}}$ diagram (Figure 6C), most of the heterogenites plot in the quadrant $\mathrm{I}\left(\log (\mathrm{La} / \mathrm{Sm})_{\mathrm{UCC}}<0\right.$ and $\left.\log (\mathrm{Gd} / \mathrm{Yb})_{\mathrm{UCC}}>0\right)$.

\section{Discussion}

Based on whole rock analyzes, it appears that heterogenite commonly exhibits three types of

REE patterns. Type 1 is enriched in middle REE, with a negative Ce anomaly and a relatively low REE content. Types 2 and 3 are variably enriched in LREE, without a Ce anomaly and with higher REE content. However, in situ LA-ICP-MS analyses reveal that the LREE enrichment of the Types 2 and 3 patterns is not related to heterogenite itself. This enrichment

21 is likely due to a mineral phase that is associated with heterogenite in the bulk Co oxidized ore.

The aim of this discussion is (1) to investigate the fractionation of the REE in a 24 supergene environment where both heterogenite and Mn-oxides form, (2) to study and model 
1 the speciation of the REE in groundwaters, and (3) to provide an improved conceptual model

2 of heterogenite formation.

4 5.1. Supergene formation of heterogenite and REE competition with coeval Mn-oxides

5 Heterogenite is a supergene mineral that precipitates from aqueous solution saturated in Co

6 (Chivot et al., 2008; Deliens, 1974; Myers and Penn, 2011). In the Katanga Copperbelt,

7 heterogenite is deposited by near-surface fluids whereas $\mathrm{Cu}$ remains in the solution and 8 percolates downwards (Decrée et al., 2010). These processes are overall similar to those 9 leading to the formation of other supergene deposits that develop on various metasedimentary 10 rocks in Katanga, including the Kisenge Mn-oxide rich caps and the widely exposed Fe11 laterites (Decrée et al., 2010). In this environment, heterogenite behaves similar to manganese oxide. $\mathrm{CoOOH}$ and $13 \mathrm{MnOOH}$ have the same bond length $1.92 \AA$ and similar Co-(Co, Mn) and Mn-Mn distances 142.79 vs 2.81 (Brown and Calas, 2012). Cobalt is strongly enriched in supergene deposits 15 because it is oxidized from $\mathrm{Co}^{2+}$ to the less soluble $\mathrm{Co}^{3+}$ in supergene conditions, possibly 16 through a disproportionation process as described by Hem (1978). Mn-oxide colloids 17 scavenge trace metals via adsorption - and/or co-precipitation - where hydrated cations (e.g., REE) are attracted to the negatively charged surface of manganese oxides (e.g., Pourret and Davranche, 2013). At high Co activity, heterogenite (Figure 7A) precipitates at near-neutral pH conditions as well as manganese oxide (i.e., pyrolusite, Figure 7B).

In Figure 8, one can see that the increase of the $\mathrm{Ce} / \mathrm{Ce} *$, $\mathrm{La}_{\mathrm{UCC}} / \mathrm{Yb}_{\mathrm{UCC}}, \mathrm{La}_{\mathrm{UCC}} / \mathrm{Sm} \mathrm{m}_{\mathrm{UCC}}$ and $\mathrm{Gd}_{\mathrm{UCC}} / \mathrm{Yb}_{\mathrm{UCC}}$ ratios is correlated with an increase of the MnO content. As a whole, the total REE content is also correlated to the increase in MnO. More precisely, two different trends are observed: the first trend (green arrow in Figure 8) shows a rapid increase of the above-mentioned ratios and REE content for a slight increase of $\mathrm{MnO}$ content. Whereas the 
second one (orange arrow in Figure 8) is characterized by a moderate increase of the above-

2 mentioned ratios and content for higher $\mathrm{MnO}$ contents. The presence of two different trends

3 could be related to the presence of various Mn-oxides in association with heterogenite.

4 Manganite, asbolane and lithiophorite are actually commonly encountered in the Co oxidized

5 ore, even within a single specimen. Heterogenite is also commonly amorphous or poorly-

6 crystalline, with size below micrometer (Burlet et al., 2011). In addition, Mn- and Co-oxides

7 may have highly variable crystallinity at microscopic scale and this is likely to influence

8 important characteristics such as specific surface and adsorption kinetic, even within a single 9 sample.

Despite their mineralogical similarities, Mn-oxides associated with heterogenite

5.2. REE speciation in alkaline groundwater

\subsubsection{Alkaline nature of the groundwater during heterogenite formation}

The presence of aqueous ligands, notably carbonate or hydroxide in water strongly affects REE solubility (Woods, 1990; Leybourne and Johannesson, 2008). Release of REE during weathering is strongly controlled by dissolution rates of parent rock minerals. In the Katanga Copperbelt, the Mio-Pliocene weathering event led to the dissolution of the Mines Subgroup dolomites and dolomitic shales, and the formation of karst (Buffard, 1984; De Putter et al., 2010) and heterogenite (Decrée et al., 2010). This dissolution should result in a neutral to 
1 alkaline fluid with the carbonate ion dominating in the solution. Locally, sulfate and

2 phosphate ions could play a more important role due to dissolution and alteration of sulfides

3 and P-bearing minerals such as monazite, apatite, dahlite $\left[\mathrm{Ca}_{5}\left(\mathrm{PO}_{4}, \mathrm{CO}_{3}\right)_{3} \mathrm{~F}\right](\mathrm{Kampunzu}$ et al.,

4 2005). Stability and composition of accessory minerals play a dominant role in the availability

5 and mobility of trace elements. Indeed the formation of secondary REE-minerals present as

6 secondary mineral phases in the Katanga Copperbelt (e.g., florencite-(La), françoisite-(Nd),

7 gysinite-(Nd), kamotoïte-(Y), lepersonnite-(Gd), schuilingite-(Nd), shabaite-(Nd), bijvoetite-

8 (Y); Daltry, 1992) can give us some clues for deciphering the probable ligands present in the

9 supergene ore-forming fluid (i.e., carbonates).

A simple weathering scheme, primarily based on a change in fluid chemistry, can

11 explain such observations. Acidic rain water - equilibrated with atmospheric $\mathrm{CO}_{2}-$ has a $\mathrm{pH}$

12 of $~ 5.7$. In contact with the uppermost part of the soil, the $\mathrm{pH}$ of this fluid can decrease up to

4-5, due to the decay of organic material (Nesbitt, 1979; Pourret et al., 2016). These acidic and oxidized fluids will percolate through the host rock (mineralized siltstones, shales and dolostones). As a result, (1) the mineralized host rocks are weathered, (2) the soluble major, minor and REE are removed, and (3) the fluids are progressively neutralized by the carbonates. Subsequently, in the upper part of the weathering profile (where the Type $1-$ MREE-rich - heterogenite forms), the REE are mainly adsorbed onto the surface of the neoformed secondary minerals (i.e., manganese oxides and heterogenites; Figure 7). At these circumneutral $\mathrm{pH}$, the speciation of the REE is mainly driven by the carbonate ions, the HREE being mobilized to a greater extent than the LREE (e.g. Johannesson et al., 1996). These solutions - which are still enriched in metals and REE - then migrate downwards, with a concomitant increase in the $\mathrm{pH}$. As the fluid becomes more alkaline, the REE are precipitated as carbonates (LREE-rich mineral co-precipitated with heterogenite as evoked in 
manganese oxides and heterogenites.

\subsubsection{Calculation of REE speciation in the multi-ligand groundwater}

4 In order to calculate REE speciation in groundwater while no groundwater analyses were performed on the study area (e.g. Atibu et al., 2013), the multi-ligand groundwater from

6 Wood (1990) was used. The speciation of $\mathrm{La}^{3+}, \mathrm{Eu}^{3+}, \mathrm{Lu}^{3+}$ in the multi-ligand groundwater at $7 \quad 25^{\circ} \mathrm{C}$ (given in Table VIII in (Wood, 1990)) taking into account two concentrations of manganese (allowing REE adsorption onto hydrous manganese oxide) was calculated by simultaneously solving the relevant mass-action and mass-balance equations at each $\mathrm{pH}$ using PHREEQC and PhreePlot (see section 3 for details). The concentrations of manganese were selected to represent concentrations in superficial waters (Pettersson and Ingri, 2001; Sracek et al., 2012). The ligands (i.e., chlorides, sulfates, carbonates) present in the multi-ligand groundwater from Wood (1990) are similar to those considered by Muchez and Corbella (2012) at $150^{\circ} \mathrm{C}$.

The results of these calculations are depicted in Figure 9. In the model groundwater with higher Mn concentrations (i.e., 10-4 mol/L), it is evident from figures $9 \mathrm{~A}-\mathrm{C}$ that $\mathrm{La}, \mathrm{Eu}$ and Lu: (1) exist predominately as the simple ion $\mathrm{REE}^{3+}$ and the sulfate complex $\mathrm{REESO}_{4}{ }^{+}$at $\mathrm{pH}=4-6.5,(2)$ are adsorbed on manganese oxide at $\mathrm{pH}=6.5-7.5$, (3) occur as the carbonate complex $\mathrm{REECO}_{3}{ }^{+}$at $\mathrm{pH}=7.5-9.5$, and (4) are present as the hydroxide complex $\mathrm{REEOH}^{2+}$ at $\mathrm{pH}>9.5$. In the modeling conditions considered for figures $9 \mathrm{~A}-\mathrm{C}$, only the carbonate and sulfate complexes are stable enough to significantly affect REE transport (e.g., Johannesson, 2005). More precisely, at neutral $\mathrm{pH}$ (expected values of samples), fractionation occurs in between REE. At pH 6, La and Eu are only weakly adsorbed onto Mn oxide (<10\%), whereas

$24 \mathrm{Lu}$ is strongly adsorbed to Mn oxide (>30\%). Such modeling results highlight the scenario (and resulting REE fractionation) that could occur in the upper zone of the weathering profile 
1 where Type 1 heterogenite (characterized by MREE enrichment; Figures 5 A,D) forms.

2 Figures 9D-F further illustrate the effect on speciation by changing the various ligand

3 concentrations used in the model. This second modeling scenario highlight the conditions

4 favorable for precipitation of Types 2 and 3 heterogenite and controlled by carbonates (with

5 the probable coprecipitation of heterogenite with a LREE carbonate; Figures 5 A,B,E,F).

6 Actually, if the total manganese concentration is decreased by an order of magnitude then the

7 carbonate complexes become important from pH 6.5 to 9.5 (Figures 9D-F). The carbonate

8 complexes of the REE are thus the most important inorganic species competing with Mn oxi-

9 hydroxide and responsible for the transport of REE in near neutral to slightly alkaline

10 groundwaters. The dominant carbonate complex for LREE is $\mathrm{LREECO}_{3}{ }^{+}$, whereas for HREE

11 a complex $\mathrm{HREECO}_{3}{ }^{2-}$ dominates in solution (Luo and Byrne, 2004). Among inorganic

12 complexes, carbonate complexes are more frequent in the $\mathrm{pH}$ range 7 to 9 ; above $\mathrm{pH} 9$ hydroxyl complexes prevail, and below $\mathrm{pH} 7 \mathrm{REE}^{3+}$ ions dominate, whereas the role of sulfate is subordinated (Schijf and Byrne, 2004). An increase in $\mathrm{pH}$ decreases the role of $\mathrm{REE}^{3+}$ ions, especially for HREE. The presence of Mn oxi-hydroxide substantially changes existing REE complexes. Thus, Mn oxi-hydroxides prevail within the $\mathrm{pH}$ interval 6.5 to 9 (Pourret and Davranche, 2013). At lower $\mathrm{pH}, \mathrm{REE}^{3+}$ ions are relatively more abundant and sulfate complexes such as $\mathrm{REESO}_{4}{ }^{+}$may appear, whereas an increase in $\mathrm{pH}$ leads to an increase in the role of carbonate (Wood, 1990). In this context, the impact of organic matter on REE speciation was not considered even though Tang and Johannesson (2003) and Pourret et al. (2007) demonstrated their major influence. It should also be noted that all of the estimations above are based on certain assumptions, such as equal activity of all species, comparably low REE concentration and absence of competing cations in the solution. 
1 At high Co activity, heterogenite precipitates at near-neutral $\mathrm{pH}$ conditions as well as

2 manganese oxide (i.e., manganite). REE are mainly fractionated between these two solid

3 phases (Figure 10). As cobalt activity decreases, the heterogenite stability field shifts towards

4 an alkaline $\mathrm{pH}$. In these conditions, REE speciation is mainly driven by carbonate

5 complexation and/or precipitation. Since the heterogenite patterns are enriched in LREE

6 (Figures 5 B,C,E,F), one can consider that a LREE-rich carbonate co-precipitates with and/or

7 is adsorbed onto heterogenite. This scheme is likely since (i) there is no correlation between

8 REE and $\mathrm{MnO}$ or $\mathrm{P}_{2} \mathrm{O}_{5}$ contents in the studied whole rock and (ii) REE-carbonates (as

9 gysinite- $\left.(\mathrm{Nd})\left[\mathrm{Pb}(\mathrm{Nd}, \mathrm{La})\left(\mathrm{CO}_{3}\right)_{2}(\mathrm{OH}) \cdot \mathrm{H}_{2} \mathrm{O}\right]\right)$ are found in the oxidized part of numerous

10 deposits of the Katanga Copperbelt (Daltry, 1992). In any case, the association of heterogenite

11 with this mineral gives the LREE-rich Type 2 and Type 3 patterns illustrated in Figures 5B

12 and $5 \mathrm{C}$.

Both REE signatures (MREE-enriched Type 1 on the one hand and LREE-enriched

Types 2 and 3 on the other hand) are consistent with the formation of heterogenite in a two-

step per descensum model, in which this mineral (i) forms as residual deposits - similar to laterite - in association with Mn-oxide, in the immediate near-surface environment, with an obvious REE fractionation between these two mineral phases, and (ii) is deposited from a carbonate-bearing fluid due to country rock dissolution in the deeper parts of the oxidation profile, in association with REE-rich carbonates (Figure 10).

The weathering of primary sulfide minerals (carrollite from the Kamoto mine, sample RGM 13024, and siegenite from the Shinkolobwe mine, sample GE 3101, Figure 5A) constitutes an important mobile REE reservoir. As demonstrated in Figure 5A, heterogenite actually displays REE patterns that are quite close to the parental Co-sulfides, being more enriched that the latter but with preservation and even enhancement of the MREE-enrichment. 
1 compared to those invoked to explain the preservation of the isotopic $\mathrm{U}-\mathrm{Pb}$ system within

2 heterogenite (Decrée et al., 2014), namely the trapping of relict nanoparticles and/or the

3 sorption of these elements. By passing through Mn-rich horizons the fluids become enriched

4 in manganese and thereby promote REE release from their carbonate support favouring Mn

5 oxides sorption (Pourret et al., 2014). Finally, the observed cerium anomalies are interpreted

6 to be the result of oxidizing conditions affecting the valence state of Ce, especially oxidation

7 scavenging together with Mn oxi-hydroxides (Pourret et al., 2014).

8

\section{6. Concluding remarks}

10 Heterogenite $(\mathrm{CoOOH})$ was deposited by near-surface fluids during the weathering of the

11 sulfide-bearing Mine Series, in the Katanga Copperbelt. A detailed study of this supergene 12 deposit based on bulk and LA-ICP-MS analyzes gives new keys to understand the processes 13 leading to heterogenite formation. Heterogenite commonly exhibits the following REE 14 characteristics: a MREE-enriched pattern, negative Ce anomaly and overall low concentration 15 in REE. When heterogenite is finely admixed with Mn-oxides, the resulting REE patterns are 16 flatter, the negative Ce anomaly is smaller (or may even be slightly positive) and the total 17 concentration in REE is higher. This suggests that fractionation of REE occurs between Coand Mn-oxide minerals in the upper part of the weathering profile. In the deeper part of the profile, Co activity decreases and the downward migration of the fluids induces dolostone dissolution. As a consequence, heterogenite precipitates from alkaline groundwater in association with a LREE-rich mineral, which notably controls the REE speciation.

\section{Acknowledgments}

24 This study is a contribution to the GECO project, funded by the Belgian Federal Public 25 Service for Foreign Affairs. The author would like to warmly thank the MRAC for providing 
1 the study samples. Luc André and Laurence Monin are also thanked for their role in providing

2 LA-ICP-MS analyzes. Editors and an anonymous reviewer are sincerely thanked for the

3 editorial handling of the manuscript and their help to improve the quality of this work.

4 Thomas Goovaerts (RBINS) is thanked for the English reviewing of the manuscript.

\section{References}

7 Atibu, E. K., Devarajan, N., Thevenon, F., Mwanamoki, P. M., Tshibanda, J. B., Mpiana, P. T., Prabakar, K., Mubedi, J. I., Wildi, W., Poté, J., 2013. Concentration of metals in surface water and sediment of Luilu and Musonoie Rivers, Kolwezi-Katanga, Democratic Republic of Congo. Applied Geochemistry 39, 26-32.

Brown, G.E., Calas, G., 2012. Mineral-Aqueous Solution Interfaces and Their Impact on the Environment. Geochemical Perspective 1 (4-5), 483-742.

Burlet, C., Vanbrabant, Y., Goethals, H., Thys, T., Dupin, L., 2011. Raman spectroscopy as a tool to characterize heterogenite $(\mathrm{CoO} \cdot \mathrm{OH})$ (Katanga Province, Democratic Republic of Congo). Spectrochimica Acta - Part A: Molecular and Biomolecular Spectroscopy

Byrne, R.H., Li, B., 1995. Comparative complexation behavior of the rare earths. GeochimIca et Cosmochimica Acta 59, 4575-4589.

Cailteux, J.L.H., Kampunzu, A.B., Lerouge, C., Kaputo, A.K., Milesi, J.P., 2005. Genesis of sediment-hosted stratiform copper-cobalt deposits, central African Copperbelt. Journal of African Earth Sciences 42 (1-5), 134-158.

Chivot, J., Mendoza, L., Mansour, C., Pauporté, T., Cassir, M., 2008. New insight in the behaviour of $\mathrm{Co}-\mathrm{H} 2 \mathrm{O}$ system at $25-150{ }^{\circ} \mathrm{C}$, based on revised Pourbaix diagrams. Corrosion Science 50 (1), 62-69. 
1 Collins, R.N., Kinsela, A.S., 2010. The aqueous phase speciation and chemistry of cobalt in terrestrial environments. Chemosphere 79 (8), 763-771.

Daltry, V.D.C., 1992. The type mineralogy of Africa: Zaire. Annales de la Société Géologique de Belgique 115, 33-62.

De Putter, T., Mees, F., Decrée, S., Dewaele, S., 2010. Malachite, an indicator of major Pliocene $\mathrm{Cu}$ remobilization in a karstic environment (Katanga, Democratic Republic of Congo). Ore Geology Reviews 38 (1-2), 90-100.

De Putter, T., Decrée, S., Banza Lubaba Nkulu, C., Nemery, B., 2011. Mining the Katanga (DRC) Copperbelt: geological aspects and impacts on public health and the environment - towards a holistic approach. IGCP/SIDA Project 594, Inaugural Workshop, Kitwe, Zambia, book of abstracts, 14-17. Available online at: http://www.geology.cz/igcp594/kitwe/PROCEEDINGS-OF-

\section{$\underline{\text { THE\%20WORKSHOP.pdf }}$}

Decrée, S., Deloule, E., Ruffet, G., Dewaele, S., Mees, F., Marignac, C., Yans, J., De Putter, T., 2010. Geodynamic and climate controls in the formation of Mio-Pliocene world class oxidized cobalt and manganes ores in the Katanga province, DR Congo. Mineralium Deposita 45, 621-629.

Decrée, S., Deloule, É., De Putter, T., Dewaele, S., Mees, F., Yans, J., Marignac, C., 2011. SIMS U-Pb dating of uranium mineralization in the Katanga Copperbelt: Constraints for the geodynamic context. Ore Geology Reviews 40 (1), 81-89.

Decrée, S., Deloule, E., De Putter, T., Dewaele, S., Mees, F., Baele, J.M., Marignac, C., 2014. Dating of U-rich heterogenite from the Katanga Copperbelt: new insights into U deposit genesis and U cycling. Precambrian Research 241, 17-28.

Deliens, M., 1974. Les Oxydes Hydrates de Cobalt du Shaba Méridional. Annales du Musée Royal de l'Afrique Centrale, Sciences Géologiques 76, 80 p. 
1 Deliens, M., Goethals, H., 1973. Polytypism of heterogenite. Mineralogical Magazine 39, 152-157.

Dewaele, S., Muchez, P., Vets, J., Fernandez-Alonzo, M., Tack, L., 2006. Multiphase origin of the $\mathrm{Cu}$-Co ore deposits in the western part of the Lufilian fold-and-thrust belt, Katanga (Democratic Republic of Congo). Journal of African Earth Sciences 46 (5), 455-469.

Dzemua GL, Gleeson SA, Schofield PF (2013) Mineralogical characterization of the Nkamouna Co-Mn laterite ore, southeast Cameroon. Miner Deposita 48:155-171.El Desouky, H.A., Muchez, P., Cailteux, J., 2009. Two Cu-Co sulfide phases and contrasting fluid systems in the Katanga Copperbelt, Democratic Republic of Congo. Ore Geology Reviews 36 (4), 315-332.

El Desouky, H.A., Muchez, P., Boyce, A.J., Schneider, J., Cailteux, J.L.H., Dewaele, S., von Quadt, A., 2010. Genesis of sediment-hosted stratiform copper-cobalt mineralization at Luiswishi and Kamoto, Katanga Copperbelt (Democratic Republic of Congo). Mineralium Deposita 45 (8), 735-763.

François, A., 1974. Stratigraphie , tectonique et minéralisations dans l'Arc cuprifère du Shaba (Rép.du Zaïre), in: Bartholomé, P. (Ed.), Gisements stratiformes et provinces cuprifères. Centenaire de la Société Géologique de Belgique, Liège, pp. 79-101.

Gauthier, G., Deliens, M., 1999. Cobalt minerals of the Katanga Crescent, Congo. Mineralogical Records 30 (4), 255-273.

Gleeson, S.A., Herrington, R.J., Durango, J., Velasquez, C.A., Koll, G., 2004. The Mineralogy and Geochemistry of the Cerro Matoso S.A. Ni Laterite Deposit, Montelíbano, Colombia. Economic Geolology 99, 1197-1213. 
Haest, M., Muchez, P., 2011. Stratiform and Vein-Type Deposits in The Pan-African Orogen in Central and Southern Africa: Evidence for Multiphase Mineralisation. Geologica Belgica 14 (1-2), 23-44.

Haest, M., Muchez, P., Dewaele, S., Boyce, A.J., von Quadt, A., Schneider, J., 2009. Petrographic, fluid inclusion and isotopic study of the Dikulushi $\mathrm{Cu}-\mathrm{Ag}$ deposit, Katanga (D.R.C.): Implications for exploration. Mineralium Deposita 44 (5), 505-522.

Haest, M., Muchez, P., Dewaele, S., Franey, N., Tyler, R., 2007. Structural control on the Dikulushi $\mathrm{Cu}-\mathrm{Ag}$ deposit, Katanga, Democratic republic of Congo. Economic Geolology 102 (7), 1321-1333.

Hem, J.D., 1978. Redox processes at surfaces of manganese oxide and their effects on aqueous metal ions. Chemical Geology 21 (3-4), 199-218.

Hem, J.D., Roberson, C.E., Lind, C.J., 1985. Thermodynamic stability of CoOOH and its coprecipitation with manganese. Geochimica et Cosmochimica Acta 49 (3), 801-810.

Hey, M.H., 1962. Cobaltic hydroxyde in nature. Mineralogical Magazine 33, 253-259.

Hitzman, M., Kirkham, R., Broughton, D., Thorson, J., Selley, D., 2005. The sediment-hosted stratiform copper ore system, Economic Geology: one hundredth anniversary volume, 1905-2005. Society of Economic Geologists, Littleton, CO, USA, pp. 609-642.

Hotz, P.E., 1964. Nickeliferous laterites in Southwestern Oregon and Northwestern California. Economic Geology 59, 355-396.

Hummel, W., Berner, U., Curti, E., Pearson, F.J., Thoenen, T., 2002. Nagra / PSI Chemical Thermodynamic Data Base 01/01. Universal Publishers, Parkland, Florida.

ICDD, 2003. JCPDS PDF-2 database. ICDD, Newton Square, PA, U.S.A.

Johannesson, K.H., 2005. Rare Earth Elements in Groundwater Flow Systems. Springer, Dordrecht. 
1 Johannesson, K.H., Stetzenbach, K.J., Hodge, V.F., Lyons, W.B., 1996. Rare earth element complexation behavior in circumneutral $\mathrm{pH}$ groundwaters: Assessing the role of carbonate and phosphate ions. Earth Planetary Science Letters 139, 305-319

Johannesson, K.H., Hendry, M.J., 2000. Rare earth element geochemistry of groundwaters from a thick till and clay-rich aquitard sequence, Saskatchewan, Canada. Geochimica et Cosmochimica Acta 64, 1493-1509.

Kampunzu, A.B., Cailteux, J.L.H., Moine, B., Loris, H.N.B.T., 2005. Geochemical characterisation, provenance, source and depositional environment of 'Roches ArgiloTalqueuses' (RAT) and Mines Subgroups sedimentary rocks in the Neoproterozoic Katangan Belt (Congo): Lithostratigraphic implications. Journal of African Earth Sciences $42(1-5), 119-133$.

Kampunzu, A.B., Cailteux, J.L.H., Kamona, A.F., Intiomale, M.M., Melcher, F., 2009. Sediment-hosted $\mathrm{Zn}-\mathrm{Pb}-\mathrm{Cu}$ deposits in the Central African Copperbelt. Ore Geology Reviews 35 (3-4), 263-297.

Kinniburgh, D.G., Cooper, D.M., 2009. PhreePlot: Creating graphical output with PHREEQC. Available at: http://www.phreeplot.org, p. 498.

Klungness, G.D., Byrne, R.H., 2000. Comparative hydrolysis behavior of the rare earths and yttrium: the influence of temperature and ionic strength. Polyhedron 19, 99-107.

Leybourne, M.I, Johannesson, K.H., 2008. Rare earth elements (REE) and yttrium in stream waters, stream sediments, and Fe-Mn oxyhydroxides: fractionation, speciation, and controls over REE $+\mathrm{Y}$ patterns in the surface environment. Geochimica et Cosmochimica Acta 72, 5962-5983.

Llorca S., Monchoux, P (1991) Supergene cobalt minerals from New-Caledonia. Canadian Mineralogist 29, 149-161 
Luo, Y.-R., Byrne, R.H., 2004. Carbonate complexation of yttrium and the rare earth elements in natural rivers. Geochimica et Cosmochimica Acta 68, 691-699.

McLennan, S.M., 2001. Relationships between the trace element composition of sedimentary rocks and upper continental crust. Geochemistry Geophysics Geosystems, 2 (4).

Migdisov, A.A., Williams-Jones, A.E., Wagner, T., 2009. An experimental study of the solubility and speciation of the Rare Earth Elements (III) in fluoride- and chloridebearing aqueous solutions at temperatures up to $300{ }^{\circ} \mathrm{C}$. Geochimica et Cosmochimica Acta 73, 7087-7109.

Muchez, P., Corbella, M., 2012. Factors controlling the precipitation of copper and cobalt minerals in sediment-hosted ore deposits: Advances and restrictions. Journal of Geochemical Exploration 118, 38-46.

Muchez, P., Vanderhaeghen, P., Desouky, H., Schneider, J., Boyce, A., Dewaele, S., Cailteux, J., 2008. Anhydrite pseudomorphs and the origin of stratiform $\mathrm{Cu}$ - Co ores in the Katangan Copperbelt (Democratic Republic of Congo). Mineralium Deposita 43 (5), $575-589$.

Myers, J.C., Penn, R.L., 2011. Controlling heterogenite particle morphology and microstructure by varying synthetic conditions. Material Research Bulletin 46, 649657.

Nesbitt, H.W., 1979. Mobility and fractionation of rare earth elements during weathering of a granodiorite. Nature 279, 206-210.

Ngongo, K., 1975. Similarity Between the Uraniferous Deposits (Shinkolobwe Type) and the Cupriferous Deposits (Kamoto Type) at Shaba, Zaire. Annales de la Société Géologique de Belgique 98 (2), 449-462.

Parkhurst, D.L., Appelo, C.A.J., 1999. User's guide to PHREEQC (Version 2) - A computer program for speciation, batch-reaction, one-dimensional transport, and inverse 

Investigations Report.

Pettersson, U.T., Ingri, J., 2001. The geochemistry of $\mathrm{Co}$ and $\mathrm{Cu}$ in the Kafue River as it drains the Copperbelt mining area, Zambia. Chemical Geology 177, 399-414.

Pourret, O., Davranche, M., Gruau, G., Dia, A., 2007. Rare Earth Elements complexation with humic acid. Chemical Geology 243, 128-141.

Pourret, O., Davranche, M., 2013. Rare earth element sorption onto hydrous manganese oxide A modeling study. Journal of Colloid Interface Sciences 395, 18-23.

Pourret, O., Lange, B., Jitaru, P., Mahy, G., Faucon, M.-P., 2014. Transfer of rare earth elements from natural metalliferous (copper and cobalt rich) soils into plant shoot biomass of metallophytes from Katanga (Democratic Republic of Congo).

Pourret, O., Lange, B., Bonhoure, J., Colinet, G., Decrée, S., Mahy, G., Séleck, M., Shutcha, M., Faucon, M.P., 2016 Assessment of soil metal distribution and environmental impact of mining in Katanga (Democratic Republic of Congo). Accepted to Applied Geochemistry.

Roqué-Rosell J, Mosselmans JFW, Proenza JA, Labrador M, Galí S, Atkinson KD, Quinn PD (2010) Sorption of Ni by "lithiophorite-asbolane" intermediates in Moa Bay lateritic deposits, eastern Cuba. Chemical Geology 275, 9-18

Schijf, J., Byrne, R.H., 2004. Determination of $\mathrm{SO}_{4} \beta_{1}$ for yttrium and the rare earth elements at $\mathrm{I}=0.66 \mathrm{~m}$ and $\mathrm{t}=25^{\circ} \mathrm{C}$-Implications for YREE solution speciation in sulfate-rich waters. Geochimica et Cosmochimica Acta 68, 2825-2837.

23 Selley, D., Broughton, D., Scott, R., Hitzman, M., Bull, S.W., Large, R.R., McGoldrick, P., Croaker, M., Pollington, N., Barra, F., 2005. A new look at the geology of the 
Zambian Copperbelt, Economic Geology: one hundredth anniversary volume, 19052005. Society of Economic Geologists, Littleton, CO, USA, pp. 965-1000.

Sracek, O., Kř́ibek, B., Mihaljevič, M., Majer, V., Veselovský, F., Vencelides, Z. Nyambe, I., 2012. Mining-related contamination of surface water and sediments of the Kafue River drainage system in the Copperbelt district, Zambia: An example of a high neutralization capacity system. Journal of Geochemical Exploration 112, 174-188.

Tang, J., Johannesson, K.H., 2003. Speciation of rare earth elements in natural terrestrial waters: Assessing the role of dissolved organic matter from the modeling approach. Geochimica et Cosmochimica Acta 67, 2321-2339.

USGS, 2013. Mineral Commodity Summaries 2014.

Wood, S.A., 1990. The aqueous geochemistry of the rare-earth elements and yttrium. 1. Review of the available low-temperature data for inorganic complexes and inorganic REE speciation in natural waters. Chemical Geology 82, 159-186.

Zeissink, H.E., 1969. The Mineralogy and Geochemistry of a Nickeliferous Laterite Profile (Greenvale, Queensland, Australia). Mineralium Deposita 4, 132-152.

\section{Figure and Table Captions}

Figure 1 Geological sketch map of the Copperbelt (modified from Cailteux et al., 2005; François, 1974). R-4 corresponds to the Mwashya Subgroup.

Figure 2 XRD patterns $(\mathrm{Cu} \mathrm{Ka})$ of representative heterogenites from the Katanga Copperbelt compared to the reference patterns (vertical lines) from the "International Centre for Diffraction Data" database (abbreviations used as follows: Ht for heterogenite, 3R for the 3R polytype, Qz for quartz, Gt for goethite, Lc for lepidocrocite, Mn for manganite, Asb for asbolan). A. Sample DOL1 from Luiswishi; B. Sample RGM 10801 from Kalabi; C. Sample RGM 10805 from Musonoi 
1 Figure 3 SEM backscattered electron images illustrating heterogenite facies in the studied

2 samples and the LA-ICP-MS analysed zones (numbers from 1 to 30). The sample name is

3 indicated on each picture (refer to Table 1 for sample origin). The abbreviations are as

4 followed: $\mathrm{Cu}$ for cuprite, FeOX for Fe-oxides, Qz for quartz. A. Botryoidal heterogenite

5 (brigh laminae) in alternation with Mn-rich oxide laminae (grey area) an in association with

$6 \mathrm{Fe}$ oxide. B. Heterogenite concretion comprising quartz grains. The dark grey laminae

7 correspond to Mn-rich layers. C. Mineral assemblage made up of heterogenite, quartz and

8 cuprite in an earthy facies. D. Heterogenite concretion comprising quartz grains and is

9 association with late cuprite concretion. The dark grey laminae correspond to Mn-rich layers.

10 E. H. and I. Botryoidal heterogenite. F. and J. Botryoidal heterogenite. The dark grey laminae

11 correspond to Mn-rich layers/zones. G. Heterogenite concretion associated with Fe oxide. K.

12 Heterogenite concretion comprising quartz grains and phyllosilicate laths from the host-rock.

13 L. Heterogenite concretion. The brighter layers correspond to laminae enriched in $\mathrm{Pb}$ and $\mathrm{U}$.

14 The dark zone results from the LA ablation.

15 Figure 4 Ternary diagrams showing the variations in terms of (A) Co-Al-Ni, (B) Co-Ni-Mn 16 of Co-rich minerals from Katanga (this study -electron microprobe analyses; Burlet et al., 17 2011; Decrée et al., 2014), New Caledonia (Llorca and Monchoux, 1991), Nkamouna 18 (Dzemua et al., 2013) and Moa Bay (Roqué-Rossell et al., 2010), and bulk lateritic ore in 19 Katanga (Co ore - heterogenite separates, this study), Cerro Matoso (Gleeson et al., 2004), 20 Greenvale (Zeissink, 1969) and Oregon (Hotz, 1964).

21 Figure 5 UCC-normalized REE patterns for heterogenites of (A) type 1 - Heterogenite 22 separates/Co oxidized ore analyses. REE patterns of Co-sulfides (carrollite from Kamoto, 23 sample RGM 13024 and siegenite from Shinkolobwe, sample GE 3101) are given for 24 comparison purposes, (B) type 2 - Heterogenite separates/Co oxidized ore analyses, (C) type 253 - Heterogenite separates/Co oxidized ore analyses, (D) type 1 - LA-ICP-MS analyses, (E) 
1 type 2 - LA-ICP-MS analyses, the additional pattern shows the difference between RGM

215884 whole rock and LA-ICP-MS analyses, (F) type 3 - LA-ICP-MS analyses, the

3 additional pattern shows the difference between TW015 Heterogenite separates/Co oxidized

4 ore and LA-ICP-MS analyses. UCC values are from McLennan (2001). Grey fields in D, E

5 and $\mathrm{F}$ represent the Heterogenite separates/Co oxidized ore analyses.

6 Figure $6 \log (\mathrm{Gd} / \mathrm{Yb})_{U C C}$ as a function of $\log (\mathrm{La} / \mathrm{Sm})_{U C C}$ illustrating REE fractionation.

7 Quadrant I corresponds to MREE enriched patterns; quadrant II to LREE enriched patterns 8 and quadrant III to HREE enriched patterns. UCC values are from McLennan (2001). (A)

9 Heterogenite separates/Co oxidized ore analyses and (B) LA-ICP-MS analyses.

10 Figure 7 Eh-pH stability diagrams at $25^{\circ} \mathrm{C}$ for (A) Co minerals and dissolved species of Co 11 (system Co-O-H only). Arrow shows heterogenite stability field shift for decreasing Co 12 activity, (B) Mn minerals and dissolved species of Mn (system Mn-O-H only).

13 Figure 8 Correlation between $\mathrm{MnO}$ content and $\mathrm{Ce}$ anomaly (A), $\mathrm{La}_{U C C} / \mathrm{Yb}_{\mathrm{UCC}}$ (B), $14 \mathrm{La}_{\mathrm{UCC}} / \mathrm{Sm}_{\mathrm{UCC}}(\mathrm{C}), \mathrm{Gd}_{\mathrm{UCC}} / \mathrm{Yb}_{\mathrm{UCC}}(\mathrm{D})$, and total REE content (E) within heterogenite (electron 15 microprobe analyses for the MnO contents and LA-ICP-MS analyses for the REE 16 contents).Two trends are observed and emphasized by arrows, see text for further details.

17 Figure 9 Speciation calculations for (a) $\mathrm{La}$, (b) Eu and (c) Lu in groundwater with [Mn] of $1810^{-4} \mathrm{~mol} / \mathrm{L}$ (d) $\mathrm{La}$, (e) Eu and (f) $\mathrm{Lu}$ in groundwater with [Mn] of $10^{-5} \mathrm{~mol} / \mathrm{L}$ (conditions of 19 groundwater from Wood, 1990). It must be noted that minor $\mathrm{F}, \mathrm{Cl}$ and $\mathrm{P}$ complexes (few \% at 20 maximum) are not depicted for clarity.

21 Figure 10 Sketch diagram illustrating the formation of the different types of heterogenite and 22 their corresponding REE patterns. The latter depend on the environment (subsurface or deeper 23 environment) and on the co-precipitating mineral phases (MnOOH or LREE-enriched 24 carbonate). REE patterns from Katanga Fe-Mn laterites are from Pourret et al. (2014). 
1 Table 1 Location and brief description of the studied heterogenites. 
Click here to download Table: Table 1 - REE Heterogenite.docx

\begin{tabular}{|c|c|c|}
\hline Sample & Location & Macroscopic description \\
\hline \multicolumn{3}{|c|}{ Eastern part of the Katanga Copperbelt } \\
\hline RGM 914 & Kiola & heterogenite masses \\
\hline RGM 924 & Kiola & heterogenite geode lining \\
\hline RGM 3334 & Ruashi & impregnation and black layers \\
\hline RGM 4418 & Lwiswishi & earthy and scoriaceous material \\
\hline DOL1 & Luiswishi & crust made up of small botryoids as fissure infillings \\
\hline RGM 1304 & Etoile & finely banded heterogenite \\
\hline \multicolumn{3}{|c|}{ Central part of the Katanga Copperbelt } \\
\hline RGM 660 & Likasi & black mass with malachite crust \\
\hline RGM 2839 & Mindigi & scoriaceous block covered with black botryoids \\
\hline RGM 12979 & Mindigi & nodular heterogenite \\
\hline RGM 10801 & Kalabi & large botryodids \\
\hline RGM 3335 & Kalabi & impregnation \\
\hline RGM 10807 & Kabolela & large botryodids \\
\hline RGM 12996 & Kabolela & botryoidal masses \\
\hline RGM 13017 & Kambove & crust-earthy material \\
\hline RGM 15884 & Kamwali & large botryooidal masses \\
\hline RGM 10788 & Shinko & small botryoids \\
\hline RGM 10816 & Shinko & large botryoids \\
\hline \multicolumn{3}{|c|}{ Western part of the Katanga Copperbelt } \\
\hline RGM 10805 & Musonoi & bright black reniform crust \\
\hline RGM 10793 & Musonoï & massive impregnation of light-coloured schist \\
\hline RGM 14091 & Musonoï & heterogenite impregnation \\
\hline RGM 13025 & Kamoto & heterogenite concretion comprizing silicified-rock clasts (RSC) \\
\hline RGM 015TW & Tilwezembe & crust-earthy material \\
\hline RGM 10794 & Tilwezembe & crust-earthy material \\
\hline
\end{tabular}




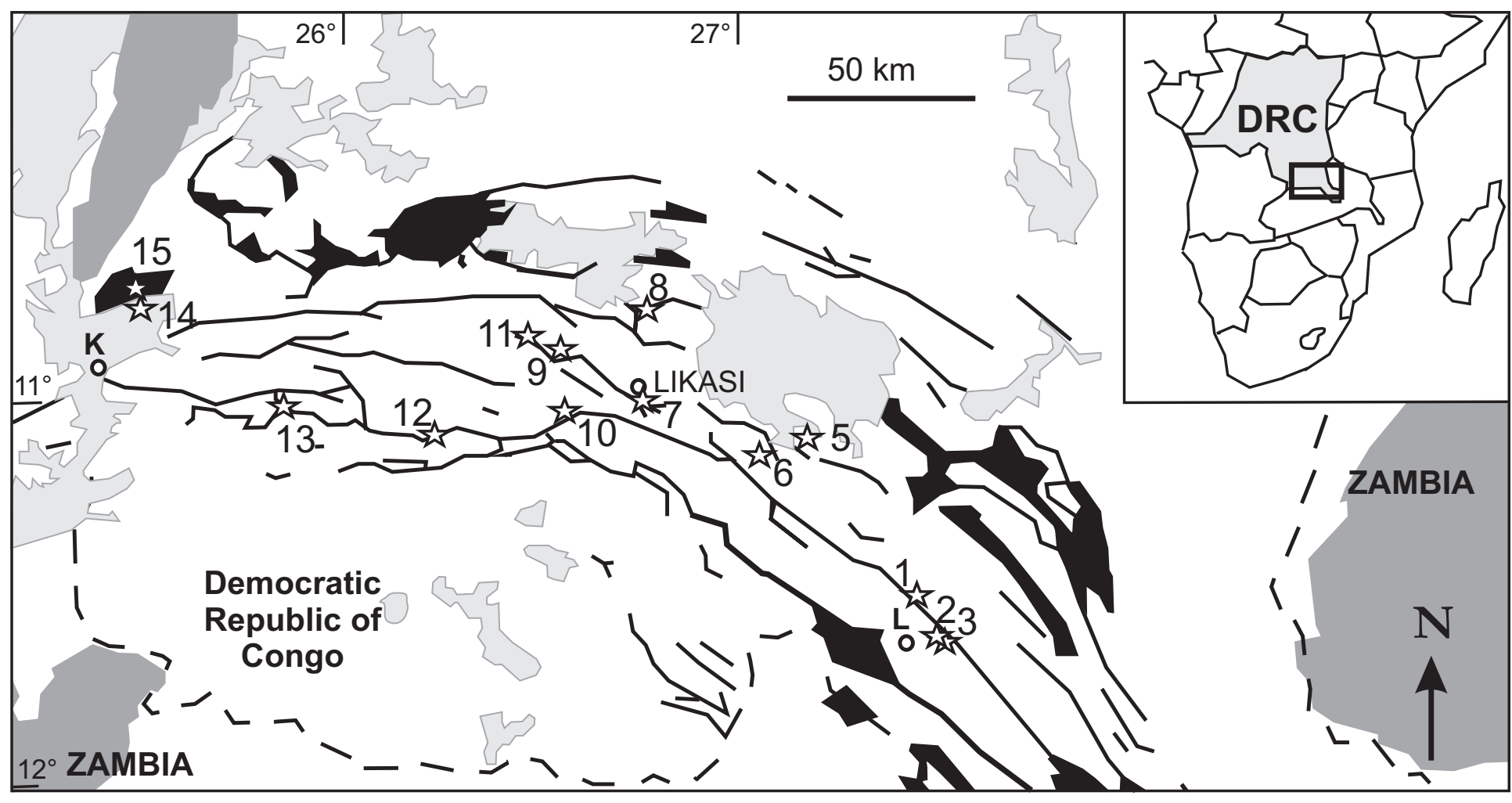

Karoo and Kalahari sediments

R-4, Nguba and Kundelungu rocks

Mines from which heterogenites have been sampled

Faults and Roan breccias

O Town

1. Luiswishi

6. Luishia

11. Kabolela

Pre-Katangan basement

K. KOLWEZI

2. Ruashi

7. Likasi

12. Mindigi

3. Etoile

8. Kalabi

4. Kiola

9. Kambove

13. Tilwezembe

L. LUBUMBASHI

5. Kamwali

10. Shinkolobwe

14. Kamoto

15. Musonoi 
Figure 2
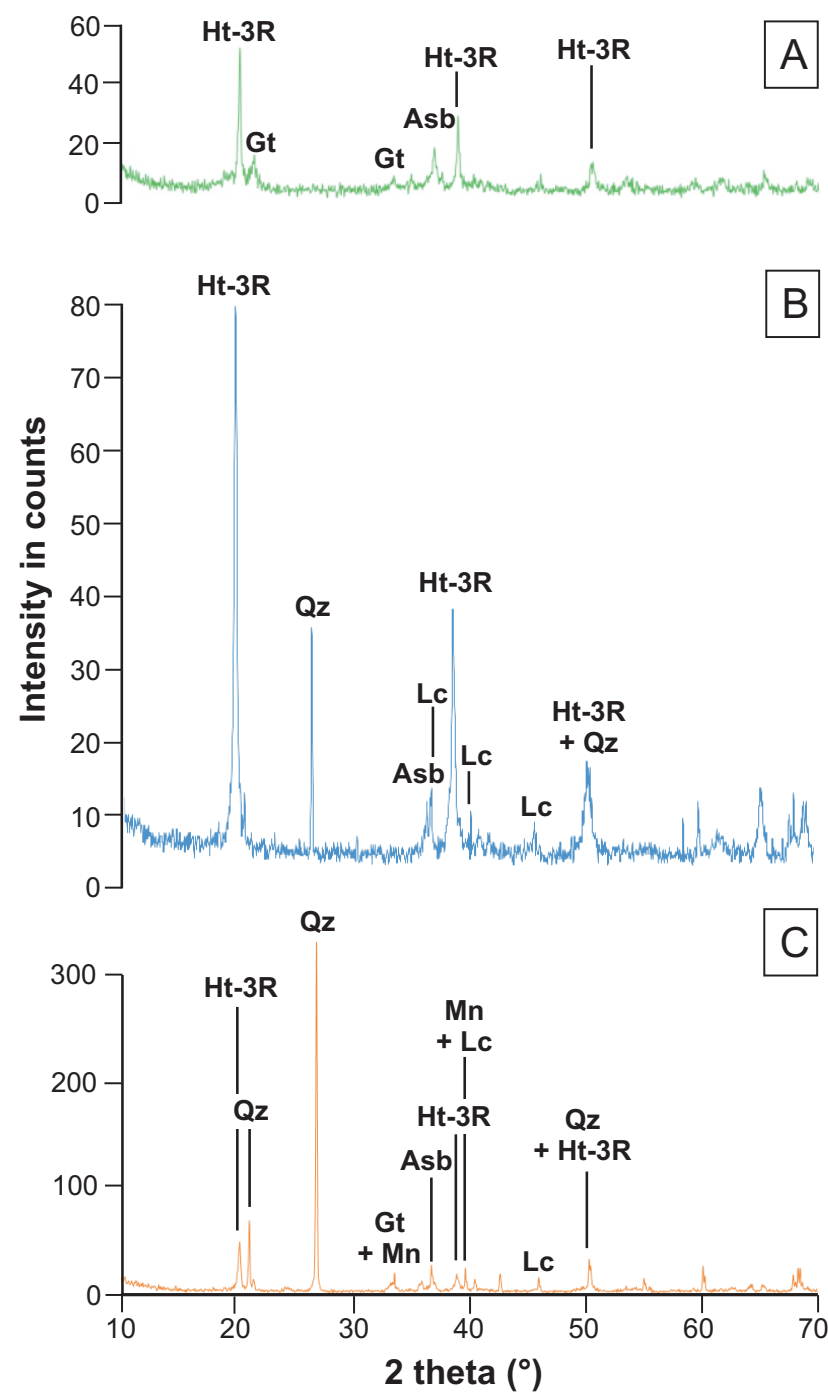

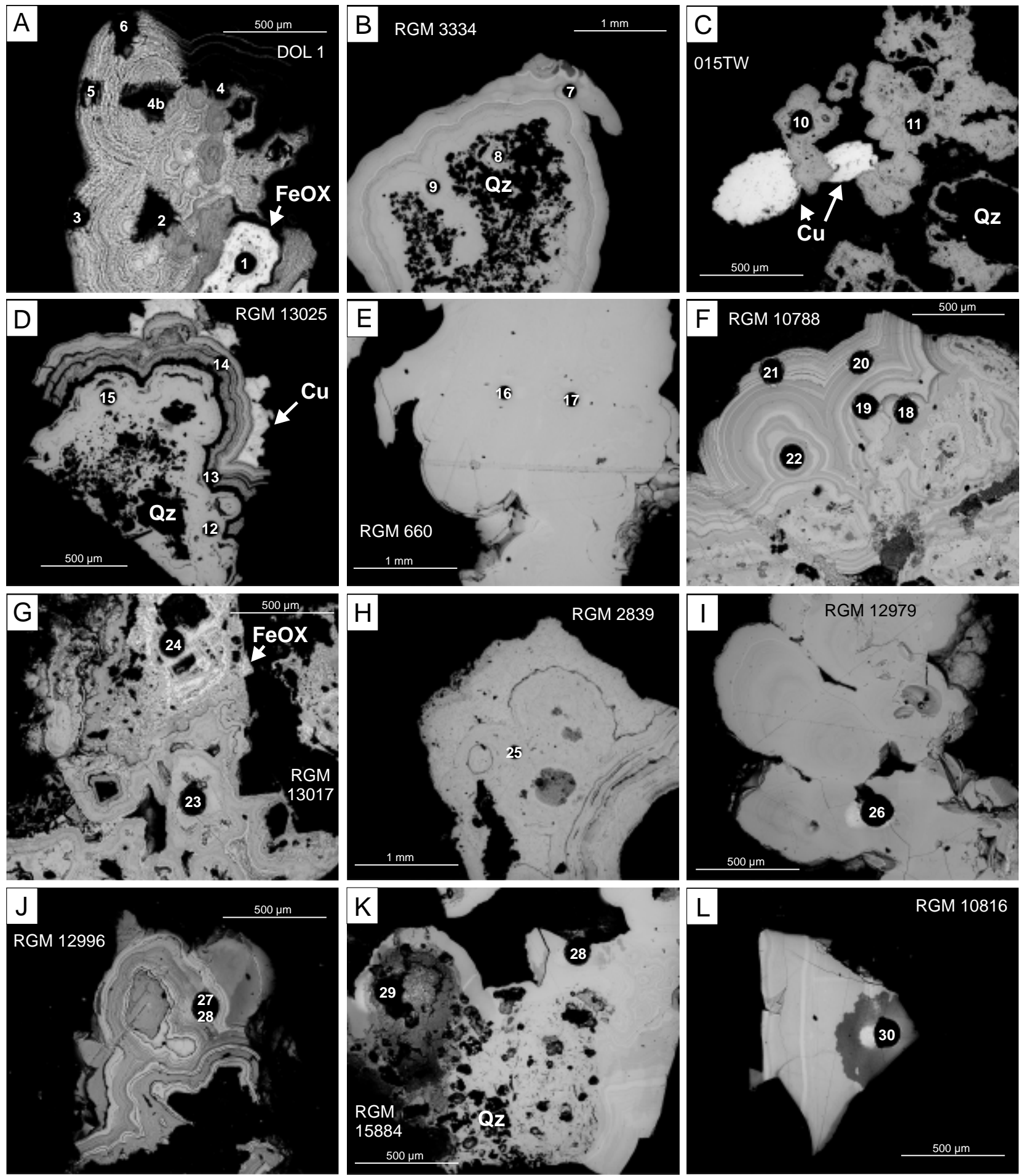


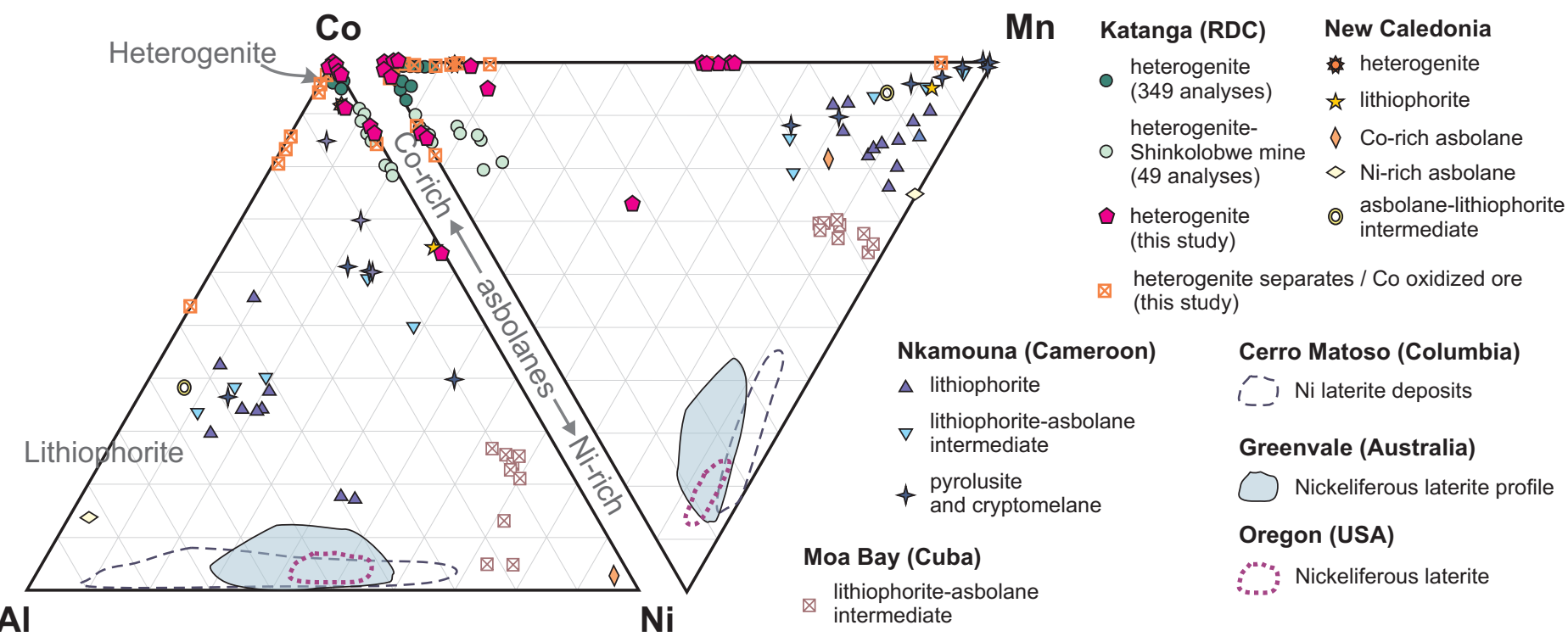


Figure 6
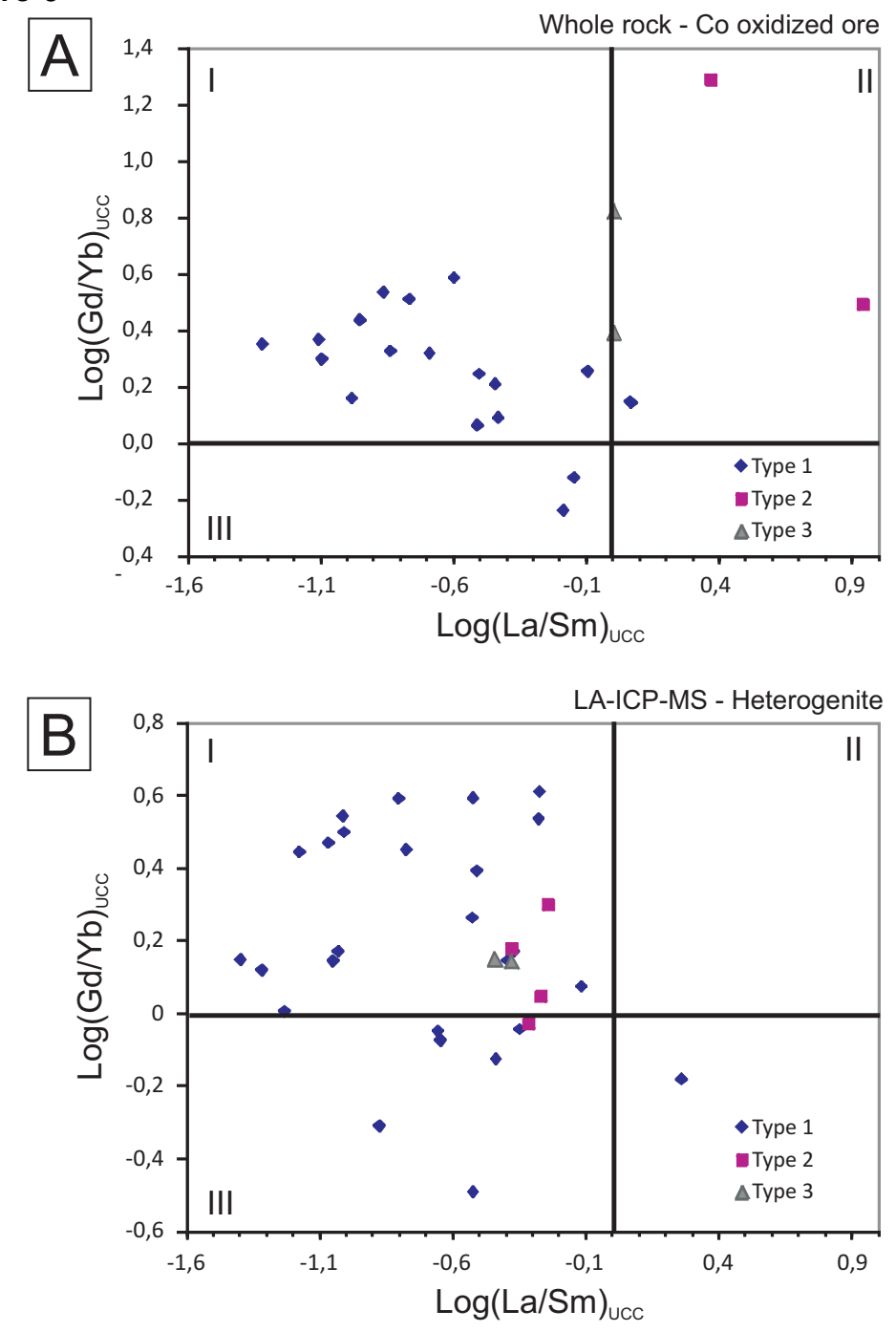
Figure 7
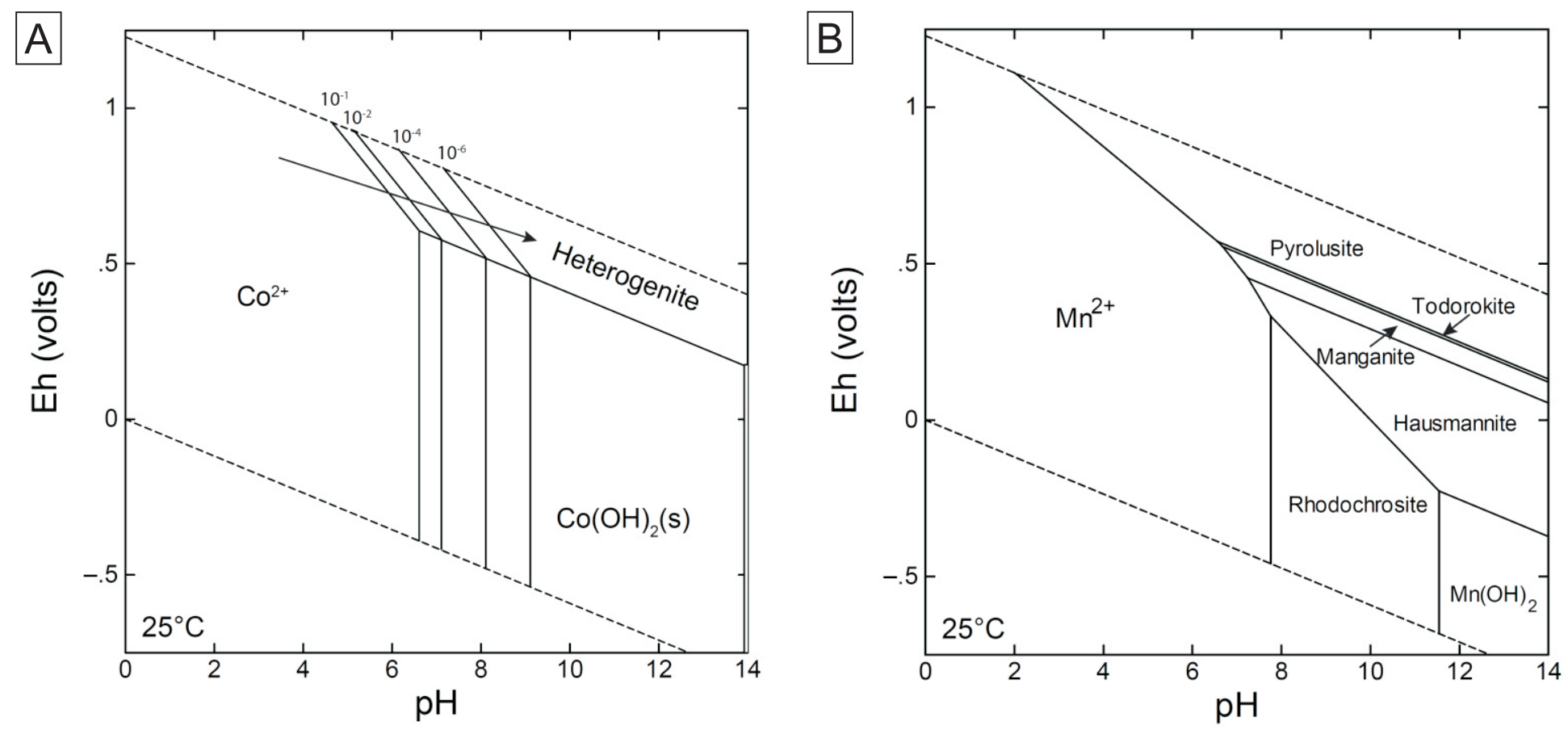


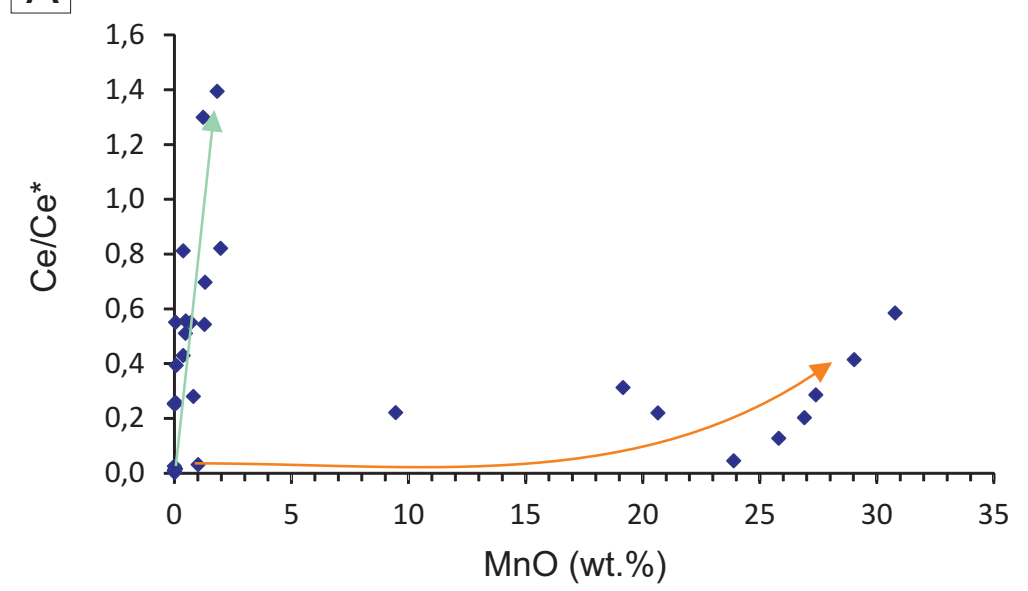

B

C

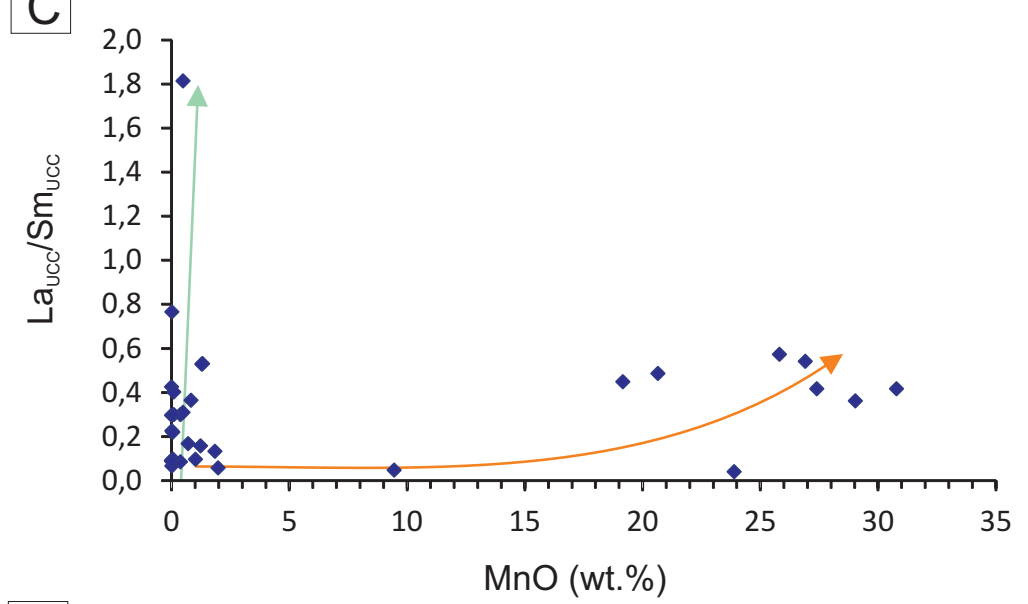

$\mathrm{E}$
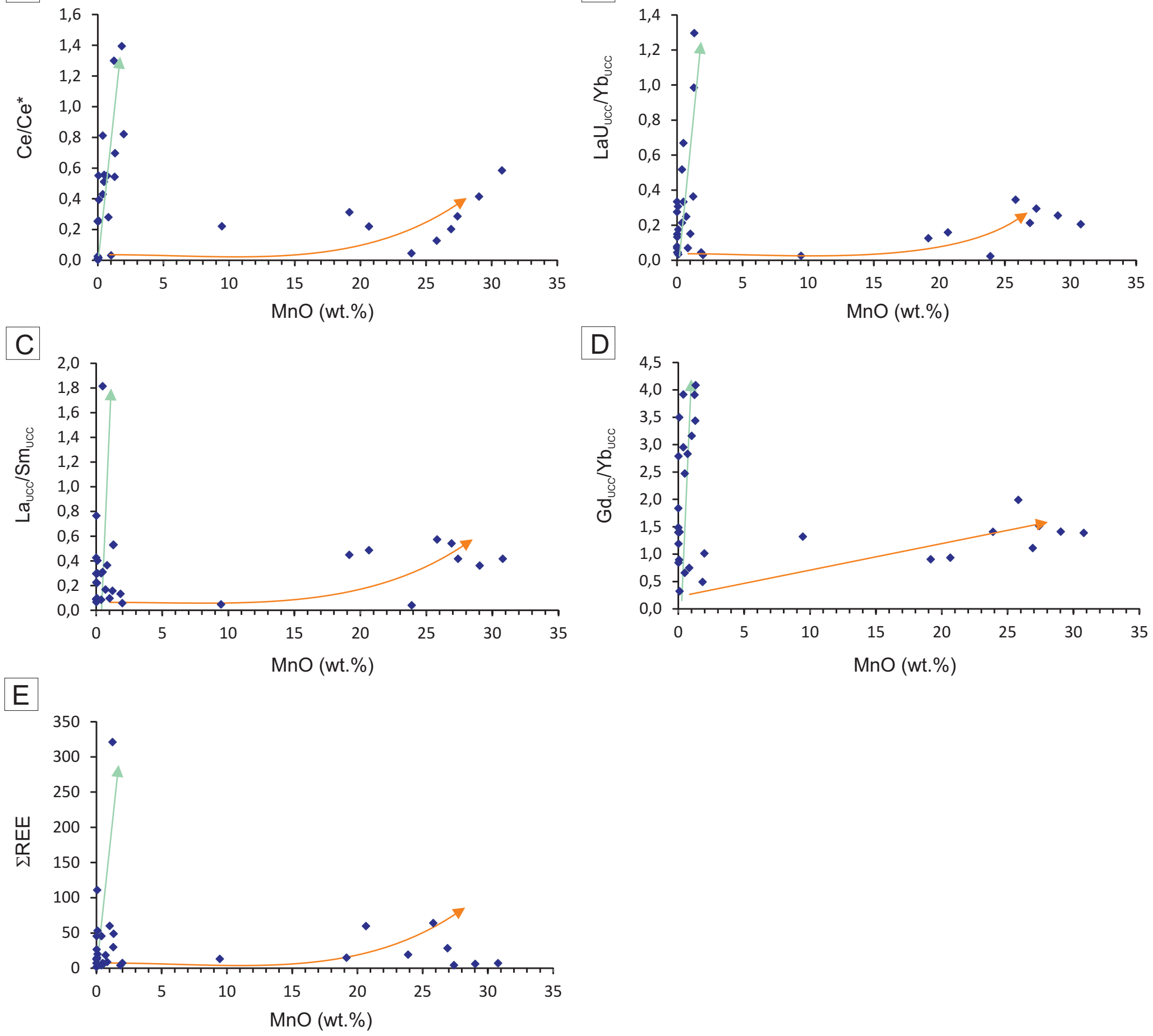
Figure 9
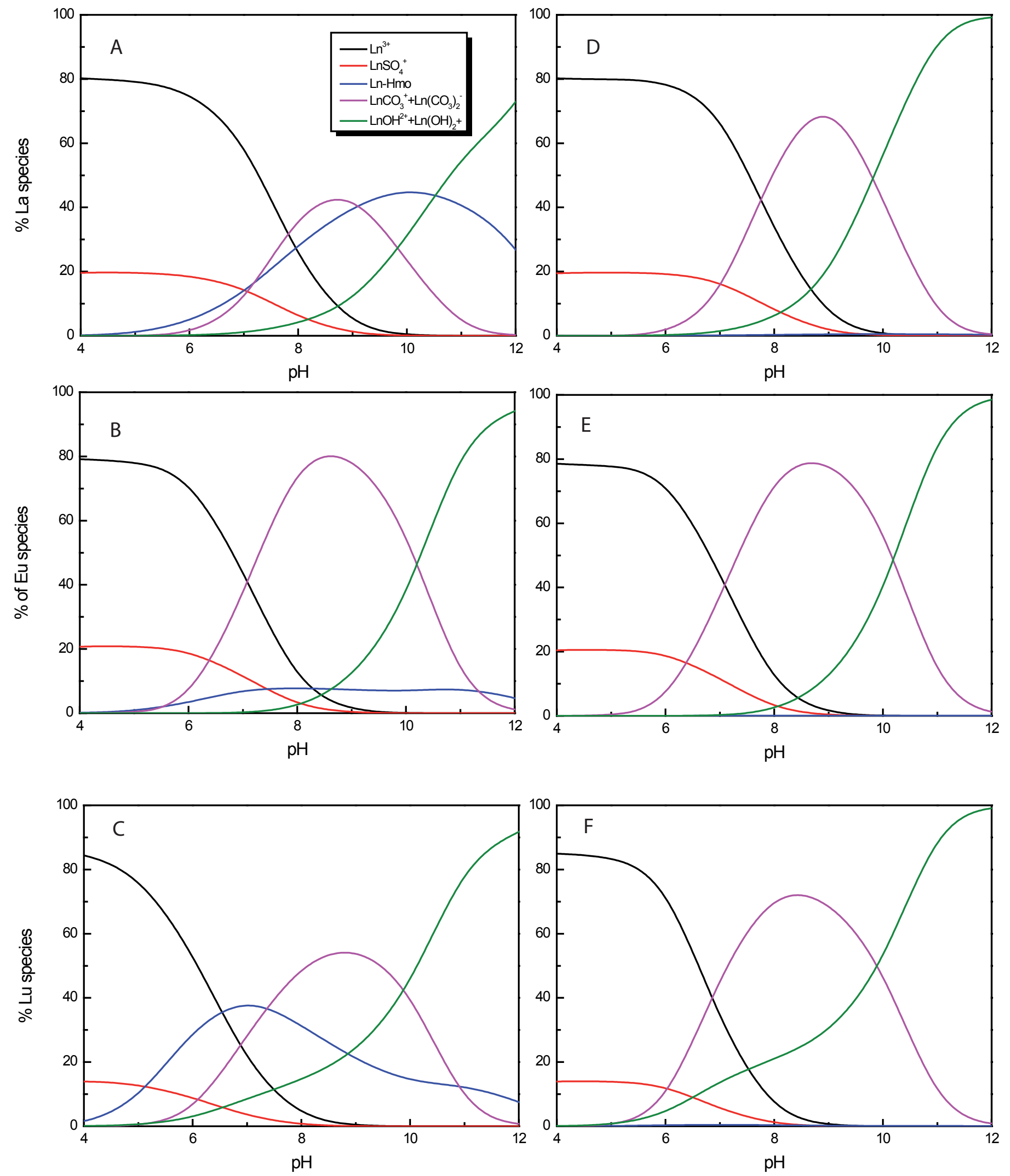


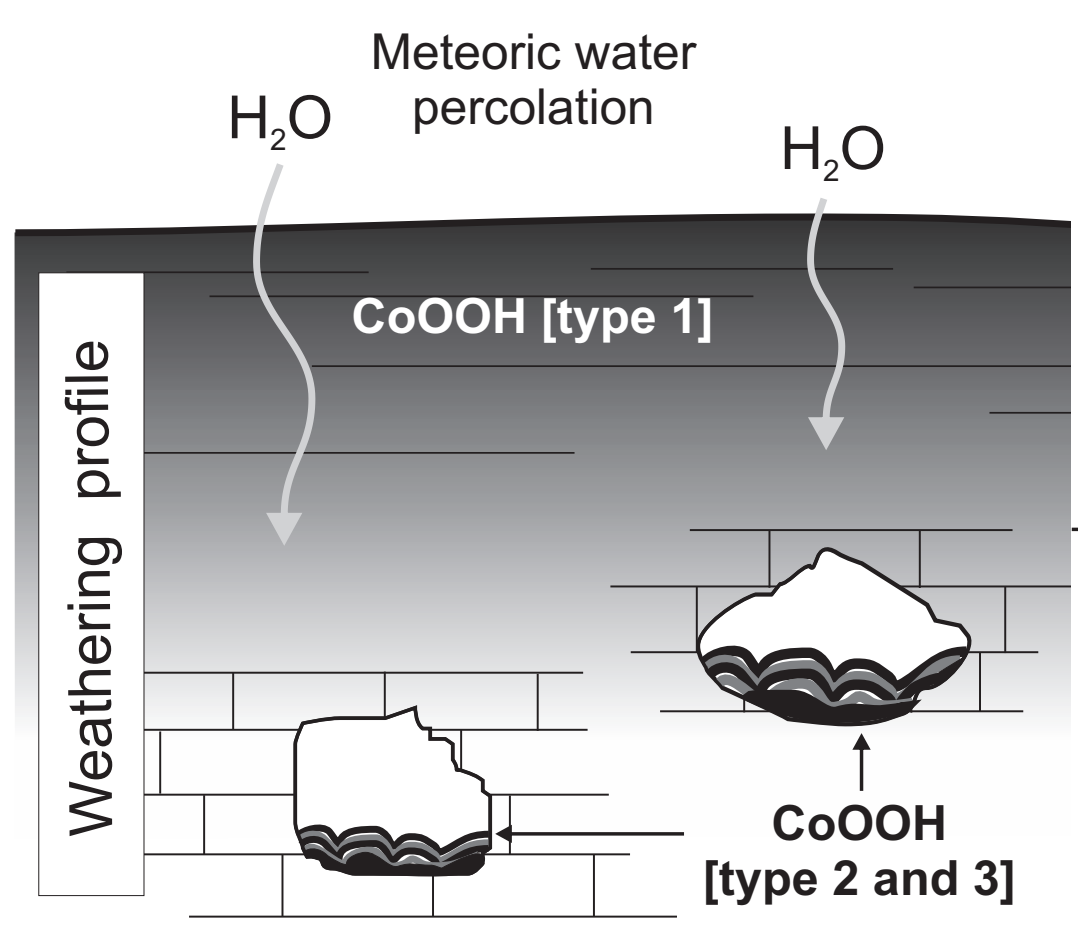

Residual deposit in near-surface environment

$\rightarrow$ Heterogenite [1] formation, in association with Mn-oxides

$\rightarrow$ Competition for REE

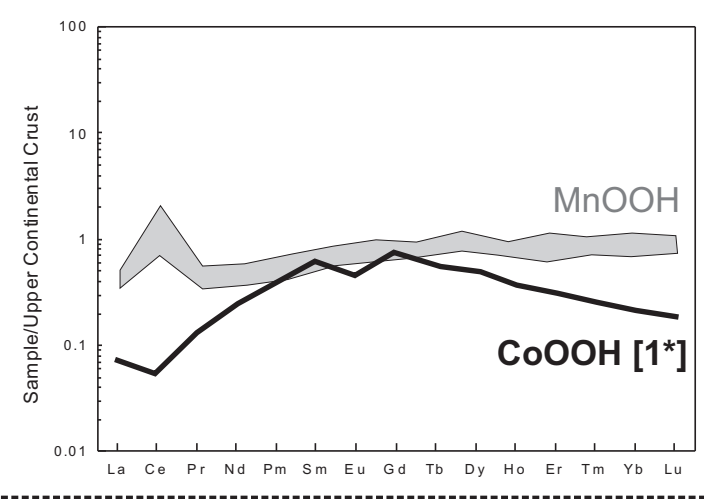

Host-rock (metasediments) dissolution

$\rightarrow$ Heterogenite [2 \& 3] formation from a carbonate-bearing fluid

$\rightarrow$ Probable coprecipitation with a LREE-rich carbonate

[*] LA-ICP-MS analysis

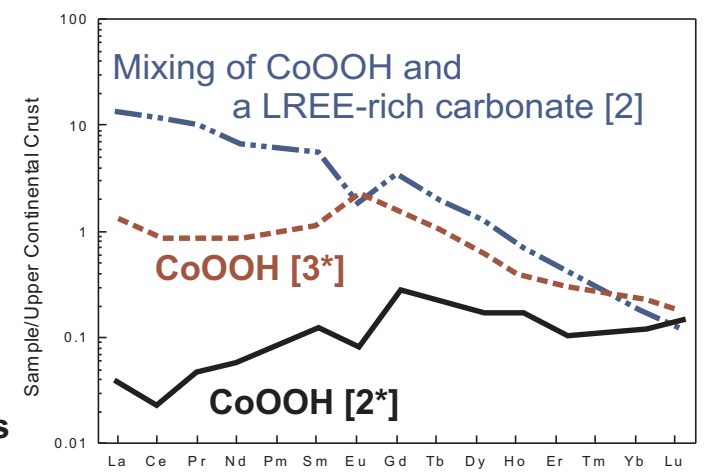




\section{Authorship Confirmation}

Please save a copy of this file, complete and upload as the "Confirmation of Authorship" file.

As corresponding author I, Sophie Decrée, hereby confirm on behalf of all authors that:

1. This manuscript, or a large part of it, has not been published, was not, and is not being submitted to any other journal. If presented at a conference, the conference is identified. If published in conference proceedings, the publication is identified below and substantial justification for re-publication must be presented.

2. All text and graphics, except for those marked with sources, are original works of the authors, and all necessary permissions for publication were secured prior to submission of the manuscript.

3. All authors each made a significant contribution to the research reported and have read and approved the submitted manuscript.

Date February, 182015

Previous conference presentation

Goldschmidt 2013 (poster)

Previous conference proceedings publication

Goldschmidt 2013 - Abstract book. P.960

Justification for re-publication 